\title{
VIRAL HEPATITIS IN THE PERUVIAN AMAZON: ETHNOMEDICAL CONTEXT AND PHYTOMEDICAL RESSOURCES
}

Vincent Roumy $^{\mathrm{a}}$, Lastenia Ruiz ${ }^{\mathrm{b}}$, Juan Celidonio Ruiz Macedo ${ }^{\mathrm{c}}$, Andrea-Luz Gutierrez- Choquevilca ${ }^{\mathrm{d}}$, Jennifer Samaillie ${ }^{\mathrm{a}}$, Leonor Arévalo Encinass, Wilfredo Ruiz Mesia ${ }^{\mathrm{b}}$, Hivelli Ericka Ricopa Cotrina ${ }^{\mathrm{b}}$, Céline Rivière $^{\mathrm{a}}$, Sevser Sahpaz ${ }^{\mathrm{a}}$, Simon Bordage ${ }^{\mathrm{a}}$, Guillaume Garçon ${ }^{\mathrm{e}}$, Jean Dubuisson ${ }^{\mathrm{f}}$, Sebastien Anthérieu $^{\mathrm{e}}$, Karin Séron ${ }^{\mathrm{f}}$, Thierry Hennebelle ${ }^{\mathrm{a}}$.

a'Univ. Lille, INRA, YNCREA, Univ. Artois, Univ. Littoral Côte d'Opale, EA 7394-ICV-Institut Charles Viollette, F-59000 Lille, France.

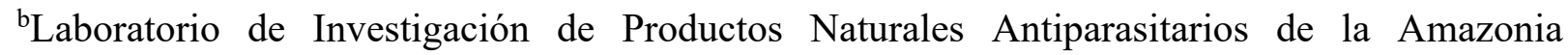
(LIPNAA), Universidad Nacional de la Amazonía Peruana (UNAP), Centro de Investigaciones de Recursos Naturales de la Amazonía (CIRNA), Nuevo San Lorenzo, Iquitos, Perú.

'Herbarium de la Amazonía Peruana Amazonense de la Universidad Nacional de la Amazonía Peruana (UNAP), Nanay con Pevas, Iquitos, Perú.

${ }^{\mathrm{d}}$ Ecole Pratique des Hautes Etudes, EPHE PSL, Laboratoire d'anthropologie sociale (UMR 7130, Collège de France, 75005 Paris, France).

eUniv. Lille, CHU Lille, Institut Pasteur de Lille, EA 4483-IMPECS-IMPact de l'Environnement Chimique sur la Santé humaine, F-59000 Lille, France.

${ }^{\mathrm{f}}$ Univ. Lille, CNRS, Inserm, CHU Lille, Institut Pasteur de Lille, U1019 - UMR 8204 - CIIL, Center for Infection and Immunity of Lille, F-59000 Lille, France.

\section{Abstract}

\section{Ethnopharmacological relevance}

An extensive ethnopharmacological survey was carried out in the Peruvian Amazonian district of Loreto with informants of various cultural origins from the surroundings of Iquitos (capital city of Loreto) and from 15 isolated riverine Quechua communities of the Pastaza River. A close attention was paid to the medical context and plant therapy, leading to the selection of 35 plant species (45 extracts). The extracts were tested for antiviral activity against HCV with counting of Huh-7 cellular death in case of toxicity, and cytotoxicity was evaluated in HepG2 cells.

\section{Aim of the study}

The aim of the study was to inventory the plants used against hepatitis in Loreto, then to evaluate their antiviral activity and to suggest a way to improve local therapeutic strategy against viral hepatitis, which is a fatal disease that is still increasing in this area.

\section{Materials and methods}


An ethnographic survey was carried out using "participant-observation" methodology and focusing on plant therapy against hepatitis including associated remedies. 45 parts of plant were extracted with methanol and tested in vitro for anti-HCV activity in 96-well plate, using HCV cell culture system with immunofluorescent detection assisted by automated confocal microscopy. Toxicity of plant extracts was also evaluated in microplates on hepatic cells by immunofluorescent detection, for the Huh-7 nuclei viability, and by UV-absorbance measurement of MTT formazan for cytotoxicity in HepG2 cells.

\section{Results}

In vitro assay revealed interesting activity of 18 extracts (50\% infection inhibition at $25 \mu \mathrm{g} / \mathrm{mL}$ ) with low cytotoxicity for 15 of them. Result analysis showed that at least $30 \%$ of HCV virus were inhibited at 25 $\mu \mathrm{g} / \mathrm{mL}$ for $60 \%$ of the plant extracts. Moreover, the ethnomedical survey showed that remedies used with low and accurate dosing as targeted therapy against hepatitis are usually more active than species indicated with more flexible dosing to alleviate symptoms of hepatic diseases.

\section{Conclusion}

Together with bibliographic data analysis, this study supported the traditional medicinal uses of many plants and contributed to a better understanding of the local medical system. It also permitted to refine the therapeutic plant indications regarding patients' liver injuries and vulnerability.

Only 2 of the 15 most active plant species have already been studied for antiviral activity against hepatitis suggesting new avenues to be followed for the 13 other species.

Keywords: Antiviral activity; Hepatitis C; Peru; Medicinal plant; Traditional use.

\section{Introduction}

Since 2017, viral hepatitis B and C have been considered as a major public health concern affecting 325 million people and leading to around 1.5 million deaths every year (WHO, 2017). Approximately $1.5-2$ million people are newly infected with viral hepatitis $\mathrm{C}$ every year, bringing the total number of the population chronically ill to 71 million in 2019 (for 150 million infected people), and causing around 400 000 deaths (Carrat et al., 2019; Petruzziello et al., 2016; Séron et al., 2018). The estimated HCV prevalence in Latin America was around 1.4\% in 2018 (MINSA, 2018), with higher prevalence in tropical area such as Peruvian Amazonia, where this study was carried out. Contrary to hepatitis $\mathrm{B}$, whose prevalence has reduced over the past decade, hepatitis $\mathrm{C}$ cannot be easily prevented by vaccination or available treatments and it became one of the most common causes of death among Amerindian populations. Moreover, the Peruvian health sector policy promotes community-based and self-supported health care services in the isolated indigenous communities. Therefore, traditional medicine remains the first recourse for treating health problems but still needs scientific evaluation

(PAHO, 2019; Mejia and 2000). In this context, attention has been paid to plant species used in traditional medicine against hepatitis and associated liver diseases in order to contribute to the "Materia medica for infectious diseases in the Amazonian district of Loreto" (Consensus Statement on Ethnopharmacological Field Studies - ConSEFS Heinrich, 2018). This study took place in the northern region of Peru called Loreto with a high level of both biodiversity and traditional knowledge. The bioprospecting was multisite and performed in Iquitos city surroundings or in Quechua/Jivaro communities along the Pastaza River. These 2 different areas were chosen to obtain more extensive data. The first one, located around Iquitos, is characterized by mixedblood native people's ethnomedical system including neighbouring Amerindian knowledge and more "conventional" medicines. The second one consisted of the riverside indigenous populations of the 
Pastaza, mainly composed of Quechua, Jivaro (Shuar, Ashuar...) and Candoa (Candoshi, Shapra) groups. In this more remote area, hepatitis is a major concern and herbalism is still the most effective treatment (Duke and Vasquez, 1994; FORMABIAP and AIDESEP, 2008).

Despite many centuries of colonisation and contemporary petroleum or forestry exploitations, the Peruvian Amazonian territory, nearly $60 \%$ of the country's area, is still inhabited by remote indigenous populations. The Pastaza River Wetland is located in Loreto and covers 3.8 million hectares, the largest tropical area of Peru. The Pastaza River begins in the Ecuadorian Andes and the mixture of this spring water with the black one from the flooded forests contributes to a very high and peculiar biodiversity. This area includes over 300 indigenous communities mainly composed of Quechua-speaking population (more than 6000 people) mixed with around 7500 Jibaroan speakers (C. Germaná, L. Lozano, 2013). Their subsistence economy relies on slash-and-burn horticulture, hunting, fishing and gathering, which contributes to the maintenance of large forest areas. Their elementary conception and exchange with their natural environment is based on the animism. It consists in the attribution of a common subjectivity or a "soul" to every being, including plants or animals and lead to a social structuration of the relations between human beings and natural species (Descola, 2013). Sickness in many ways reveals a

disruption affecting the individual's soul and its relation with otherness, humans or non-humans. Accordingly to this belief, although this population uses many medicines, ill people mostly attend a Shaman ("yachak" in Quechua or "curandero" in Spanish; Roumy et al., 2007).

\section{Materials and methods}

\section{Ethnopharmacological survey}

The ethnobotanical study was conducted during humanitarian missions from June to August 2013, 2014 and 2016.The survey was carried out with 32 informants of various cultural origins from the surroundings of Iquitos (capital city of Loreto), and in 15 riverine Quechua communities of the Pastaza River from Santa Ana (river mouth of Pastaza) to Sabalo Yaccu (upstream remote community situated $250 \mathrm{~km}$ North, Fig.1). Cultural heterogeneity of informants permitted to gather exhaustive data on local phytotherapies. Close attention was paid to the plant therapy used against hepatitis including associated remedies (e.g. special plant diets, symptomatic treatment for jaundice and liver-related ailments). These biomedical uses of plant-derived remedies belonged to different categories according to the International Classification of Primary Care (ICPC), mainly infections and gastrointestinal disorders (Staub et al, 2015).

Information presented here was compiled through general conversations, informal interviews, rainforest walks and other activities shared with local people (harvesting, weeding, hunting, nursing...) adopting a "participant-observation" methodology. Depending on their willingness, origin and availability, the contribution of each informant was so variable that we preferred not to take the numbers of citations into account here (number of citation are just mentioned Table 1).

\section{Plant material}

The plants collected were vouchered, deposited and identified at the Herbarium of the Universidad Nacional de la Amazonia Peruana by the botanist Juan Celidonio Ruiz Macedo, (UNAP, Iquitos) and according to regional floras (Duke and Vasquez, 1994; Rutter, 1990; Velasquez, 1990). This project was realized in accordance with the Universidad Nacional de la Amazonía Peruana guidelines (Laboratorio de Investigación de Productos Naturales Antiparasitarios de la Amazonia LIPNAA, UNAP) pertaining to ethnopharmacological studies, and ethical approvals with signature from each informant were obtained before investigations. 
Plant samples were dried, powdered and extracted three times with methanol for $24 \mathrm{~h}$ and filtered $(10 \mathrm{~g}$ of powdered plant in $100 \mathrm{~mL}$ of $\mathrm{MeOH}$ ). Extracts were taken to dryness at $40{ }^{\circ} \mathrm{C}$ under vacuum and weighed. The processing of the plants performed in this study was different from the traditional preparations (Table 1). Therefore, it was not an exact replication of the traditional knowledge but it was admitted that methanolic plant extracts provided more consistent antimicrobial activities (Murphy Cowan, 1999). Moreover, methanol also provided a more complete extraction, including fewer polar compounds, and was more representative of the traditional preparations than other chemical solvents.

\section{Cytotoxicity on HepG2 cells}

Methanolic dried extracts were suspended in DMSO to obtain an original concentration of $120 \mathrm{mg} / \mathrm{mL}$. Cells were subcultured in 96-well plates with 3500 cells/well in $100 \mu \mathrm{L}$ of growth medium (Dulbecco's Modified Eagle Medium, DMEM, supplemented with $10 \%$ foetal bovine serum $50 \mathrm{U} / \mathrm{mL}$ penicillin and $50 \mu \mathrm{g} / \mathrm{mL}$ streptomycin). After $24 \mathrm{~h}$ of incubation (in humidified atmosphere, $5 \% \mathrm{CO}_{2}$ at $37{ }^{\circ} \mathrm{C}$ ), the medium was discarded and replaced with 5 dilutions of the plant extracts in DMEM (at 240, 120, 60, 30, and $15 \mu \mathrm{g} / \mathrm{mL}$ ) in quadruplicate. Cellular growth control was performed using medium with $0.2 \%$ DMSO. Then, after an incubation period of $48 \mathrm{~h}$, the medium was discarded and replaced with DMEM containing $0.5 \mathrm{mg} / \mathrm{mL}$ MTT (3-(4,5- dimethylthiazol-2-yl)-2,5-diphenyltetrazolium bromide). After $1 \mathrm{~h} 30$ of incubation at $37^{\circ} \mathrm{C}$ and $5 \% \mathrm{CO}_{2}$, the water-insoluble formazan was dissolved in $100 \mu \mathrm{L}$ DMSO and the absorbance was measured at $550 \mathrm{~nm}$ using a UV-spectrometer (Tecan, Spark 10M). The cytotoxicity of the crude extracts and standard (camptothecin: $\mathrm{IC}_{50}: 0.9 \pm 0.1 \mu \mathrm{g} / \mathrm{mL}$ ) was determined by comparing the absorbance of treated cells with the absorbance of control cells cultured in $0.2 \%$ DMSO. Data were expressed as a percentage of inhibition calculated according to the formula $(\%$ Cell viability $=$ Abs treated cells x 100 / Abs control cells) and analysed by linear regression.

\section{Anti-HCV activity}

We used HCV cell culture system (HCVcc) to perform the antiviral screening. A modified HCV strain (JFH1, genotype 2a) containing cell culture-adaptive mutations (Delgrange et al., 2007; Goueslain et al., 2010) was used. JFH1 was kindly provided by T. Wakita (National Institute of Infectious Diseases, Tokyo, Japan). The viral stocks were produced in human hepatoma Huh-7 cells. For antiviral assay, Huh-7 cells, 6000/well, seeded in 96-well plate the day before infection were inoculated with $\mathrm{HCVcc}$ at a multiplicity of infection (MOI) of 0.8 during $2 \mathrm{~h}$ at $37^{\circ} \mathrm{C}$ in the presence of plant extracts at $25 \mu \mathrm{g} / \mathrm{mL}$. Epigallocatechin-3-gallate (EGCG, Calbiochem) from green tea extract, an HCV entry inhibitor, was used as a control, inhibiting here $99.5 \%$ of HCV infection at $25 \mu \mathrm{g} / \mathrm{ml}$ (Calland et al., 2012). Then, the inoculum was removed and cells were overlaid with fresh medium containing plant extracts at $25 \mu \mathrm{g} / \mathrm{mL}$ for $28 \mathrm{~h}$ at $37^{\circ} \mathrm{C}$. After $30 \mathrm{~h}$, cells were fixed with ice-cold methanol and were subjected to immunofluorescent detection of E1 envelope protein as described (Rouillé et al., 2006). Nuclei were stained with $1 \mu \mathrm{g} / \mathrm{mL}$ of DAPI (4',6-diamidino-2-phenylindole), and infected cells were detected by immunofluorescent labeling of E1 envelope glycoprotein (A4 epitope). Confocal images were recorded using an automated confocal microscope IN Cell Analyzer 6000 (GE Healthcare Life Sciences) using a $10 \times$ objective with exposure parameters $405 / 450 \mathrm{~nm}$ and $561 / 610 \mathrm{~nm}$. Six fields per well were recorded. Each image was then processed using the Colombus image analysis software (Perkin Elmer) (Calland et al., 2015). The ratio of infected cells over total cells represents the infection rate. Infection rates in DMSO controls were expressed as $100 \%$.

Fig. 1: Maps of the North of Peru (Loreto) with studied areas.

\section{Results}

Ethnobotanical study: local uses of medicinal plants in case of "hepatitis" 
The ethnobotanical survey led to the collection and identification of 35 plant species providing 45 extracts. All the remedies were not specifically indicated in case of viral hepatitis infection but rather against hepatic injury and associated symptoms (Table 1). In such cases of infectious diseases with digestive symptoms, useful medicine against hepatitis does not necessarily have antiviral activity. Moreover, it is relevant to show how food and medicinal plant are interrelated. This ethnobotanical survey with related publications indicated that it is usual in Peruvian Amazon to find dietary and other restrictions with plants, such as sexual abstinence, or social seclusion (Sanz-Biset and Cañigueral, 2011). This dietary restriction called "dieta" in Spanish and "sasina" in lowland Quechua consists of stopping food like meat, fat, eggs, salt, sugar, spices, alcohol, until healing, and progressive reestablishment of normal diet with boiled plantains, manioc and fish. During this survey, restricted diets were mentioned for chronic or important diseases such as hepatitis and associated digestive affections. This practice also depended on plant species, preparation and administration route, or particular uses. Stronger diets may also be observed for "teaching plants", such as Aspidosperma excelsum, Hura crepitans, Jatropha curcas, Mansoa alliacea, Maytenus macrocarpa, Phyllanthus sp., Pouteria caimito. Indeed, these species are also used in apprenticeships of traditional medicine that need a ritual gathering. These particular and well-structured traditional medicinal practices are usually characterized by an important symbolic significance (Jauregui et al., 2011).

In this context, a comparative study of local uses allowed an a posteriori classification of most of the plant remedies in broadly 3 interconnected categories (A, B, C):

- A: Preparations with low and accurate dosing for targeted therapy against aetiology of liver diseases. These remedies were usually characterized by a narrow therapeutic range, associated with a special food diet and strictly contraindicated in combination with "modern medication": Aspidosperma excelsum, Hura crepitans, Jatropha curcas, Mansoa alliacea, Maytenus macrocarpa, Phyllanthus sp., Pouteria caimito, Pseudelephantopus spiralis. Most of these species were considered as "teaching plants"as mentioned above.

- B: Preparations with flexible dosing usually indicated to alleviate symptoms of hepatitis and liver injuries such as jaundice, functional digestive disorders, inflammation, ascites...: Bixa orellana, Cajanus cajan, Carica papaya seed, Crescentia cujete, Curcuma longa, Desmodium adscendens, Eryngium foetidum, Gossypium barbadense, Malachra ruderalis, Physalis angulata, Senna reticulata, Tessaria integrifolia, Urera baccifera.

- C: Preparations used without particular dosing as substitutes for food or "functional food" in order to replace contraindicated unpalatable nutrients such as animal proteins and lipids, or to drain the body: Costus erythrocoryne, Gynerium sagittatum, Cecropia ficifolia, hearts of palms (Arecaceae such as Astrocarium spp., Oenocarpus bataua), preparations called "agua de tiempo" ("drunk at any time" e.g. Scleria microcarpa, Carica papaya leaves, Persea americana).

It should be noted that a same species could belong to different categories depending on its preparation.

Fig. 1: Maps of the North of Peru (Loreto) with studied areas. 


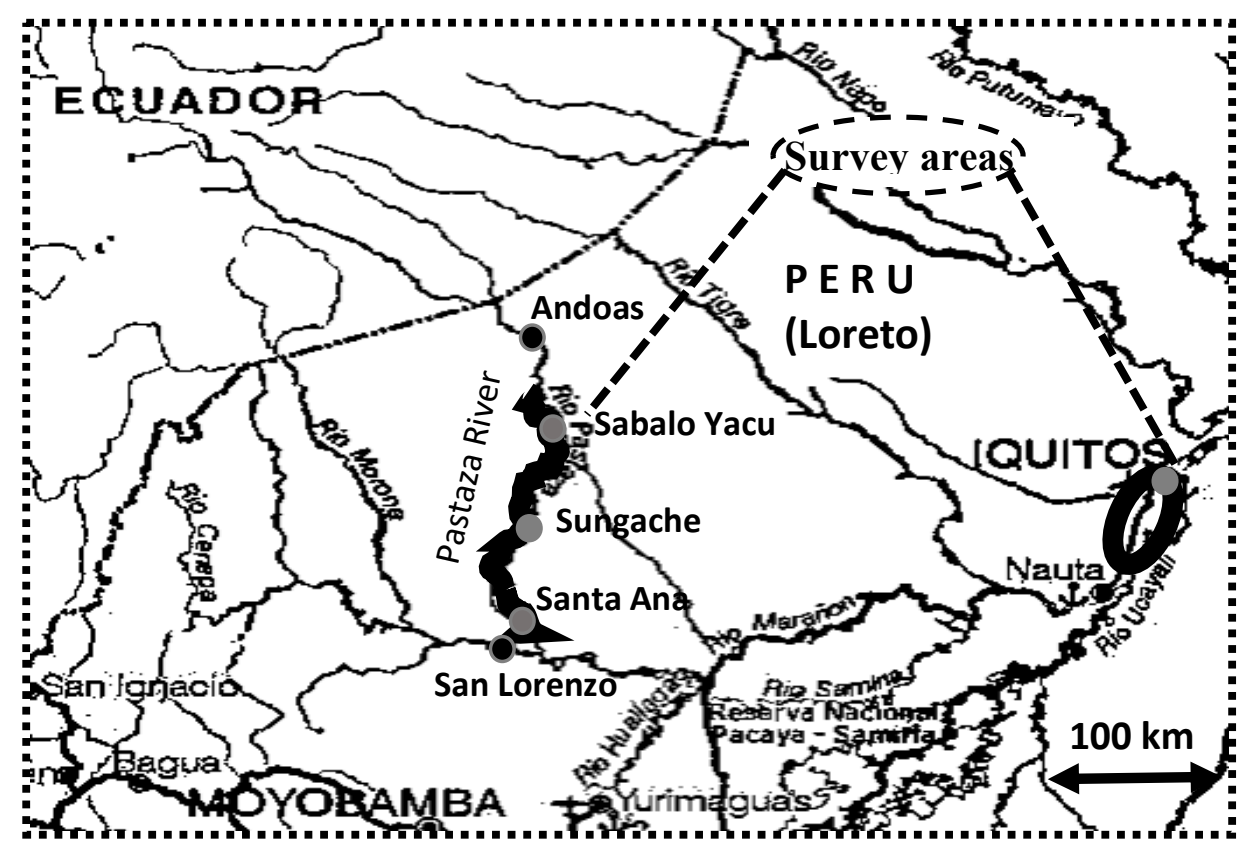


Table 1: Alphabetic list and traditional uses of plant species to treat liver diseases

\begin{tabular}{|c|c|c|c|}
\hline \begin{tabular}{|l|} 
Scientific \\
Family
\end{tabular} & $\begin{array}{l}\text { Vernacular name } \\
\text { in spanish (and } \\
\text { quechua), voucher } \\
\text { specimen }\end{array}$ & $\begin{array}{l}\text { Part } \\
\text { used }\end{array}$ & $\begin{array}{l}\text { Traditional uses to treat liver diseases (category of use: A, B or } \\
\text { C) }\end{array}$ \\
\hline \begin{tabular}{|l|} 
Aspidosperma excelsum \\
Benth., Apocynaceae
\end{tabular} & $\begin{array}{ll}\text { Remo } & \text { caspi, } \\
\text { (kawina } & \text { anku), } \\
035867 & \end{array}$ & B & $\begin{array}{l}\text { Few drops of resin diluted in water or root decoction are drunk one } \\
\text { a day in the morning with special } \operatorname{diet}^{\text {a }} \text {. (A) }\end{array}$ \\
\hline \begin{tabular}{|l|} 
Astrocaryum jauari \\
Mart., Arecaceae
\end{tabular} & $\begin{array}{l}\text { Asawachi } \\
\text { (wiririma), } 023361\end{array}$ & $\begin{array}{l}\mathrm{L} \\
\mathrm{R}\end{array}$ & $\begin{array}{l}\text { Heart of palm are boiled during } 15 \text { minutes. The decoction is drunk } \\
\text { and the palm heart is eaten } 3 \text { times a day with dietary restrictions a, } \\
\text { to "make urine pale". (C) }\end{array}$ \\
\hline $\begin{array}{l}\text { Bixa } \\
\text { Bixa }\end{array}$ & $\begin{array}{l}\text { Achiote, (mantru), } \\
026053\end{array}$ & $\mathrm{~L}$ & $\begin{array}{l}\text { Decoction of leaves is drunk against di } \\
\text { (10 leaves in } 1 \text { litre / day). (B) }\end{array}$ \\
\hline 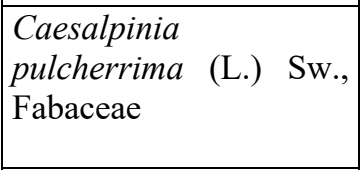 & $\begin{array}{l}\text { Chanca piedra } \\
\text { (ambiguous } \\
\text { denomination), } \\
035563\end{array}$ & $\mathrm{~L}$ & See Phyllanthus stipulatus.(NC) \\
\hline cajan (L.) Huth & $\begin{array}{l}\text { Puspo poroto, } \\
\text { (purutu), } 041695\end{array}$ & AP & 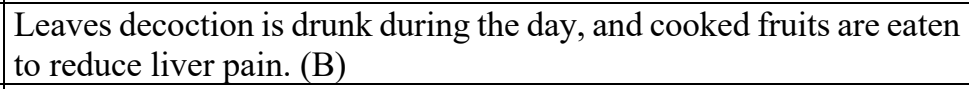 \\
\hline apaya L., & $\begin{array}{ll}\text { Papaya } \\
033863\end{array}$ & $\begin{array}{l}\mathrm{L} \\
\mathrm{S}\end{array}$ & $\begin{array}{l}\text { Root decoction is drunk during all the day as "agua de tiempo b". (C) } \\
\text { Pulverised seeds are eaten in the morning to purge the body, } \\
\text { associated with special diet }{ }^{\mathrm{a}} \text {. (B) }\end{array}$ \\
\hline $\begin{array}{|lr|}\text { Carludovica } & \text { palmata } \\
\text { Ruiz \& } & \text { Pav., } \\
\text { Cyclanthaceae } & \\
\end{array}$ & $\begin{array}{l}\text { ije, (lisand } \\
5546\end{array}$ & $\begin{array}{l}\mathrm{HP} \\
\mathrm{L}\end{array}$ & $\begin{array}{l}\text { Heart of palm and buds are boiled and drunk during the day with } \\
\text { dietary restrictions }{ }^{\text {a }} \text {. (C) }\end{array}$ \\
\hline $\begin{array}{l}\text { Cecropia ficifolia } \text { Warb. } \\
\text { ex Snethl., Urticaceae }\end{array}$ & \begin{tabular}{|l}
$\begin{array}{l}\text { Cetico sitica, } \\
\text { shuruna), }\end{array}$ 035552 \\
\end{tabular} & $\mathrm{L}$ & ter \\
\hline \begin{tabular}{|l|} 
Chamaesyce thymifolia \\
(L.) \\
Euphorbiaceae
\end{tabular} & $\begin{array}{l}\text { Cocodrilo (confused } \\
\text { with chanca piedra), } \\
025312\end{array}$ & $\begin{array}{l}\mathrm{R} \\
\mathrm{AP}\end{array}$ & See $P$ \\
\hline $\begin{array}{l}\text { Costus erythrocoryne } \\
\text { K. Schum., Costaceae }\end{array}$ & Caña agria, 032256 & AP & The fresh exudate from the stem is drunk in the morning. (C) \\
\hline $\begin{array}{l}\text { cujete L., } \\
\text { eae) }\end{array}$ & ii), & $\mathrm{L}$ & (B) \\
\hline $\begin{array}{l}\text { longa } \mathrm{L} . \\
\text { aceae }\end{array}$ & Guisador, 033866 & $\mathrm{R}$ & $\begin{array}{l}\text { The decoction (about } 1 / 4 \mathrm{~kg} \text { in one litre of water) is drunk during the } \\
\text { day with special diet, sometimes added to flowers of Senna } \\
\text { reticulata. } \\
\text { The juice is expressed from the rhizome and drunk ( } 3 \text { spoonsful per } \\
\text { day for children). Ablution with expressed leaves are realised for } \\
\text { younger children. (B) }\end{array}$ \\
\hline \begin{tabular}{|l}
$\begin{array}{l}\text { Desmodium adscendens } \\
\text { (Sw.) DC., Fabaceae }\end{array}$ \\
\end{tabular} & $\begin{array}{l}\text { Amor } \\
037518\end{array}$ & $\mathrm{AF}$ & Decoction of aerial parts (3 times a day). (B) \\
\hline $\begin{array}{l}\text { Eryngium foetidum L., } \\
\text { Apiaceae }\end{array}$ & \begin{tabular}{|ll} 
Sacha & culantro, \\
033895 & \\
\end{tabular} & $\mathrm{E}$ & (B) \\
\hline $\begin{array}{l}\text { Euterpe precatoria } \\
\text { Mart., Arecaceae }\end{array}$ & Huasay, 026315 & $\mathrm{R}$ & $\mathrm{g}$ the \\
\hline $\begin{array}{l}\text { Gossypium barbadense } \\
\text { L., Malvaceae }\end{array}$ & $\begin{array}{l}\text { Algodón blanco, } \\
\text { (utku), } 026673\end{array}$ & \begin{tabular}{|l|}
$\mathrm{Fl}$ \\
$\mathrm{L}$ \\
\end{tabular} & flowers (one handful, sometimes with leaves) is \\
\hline 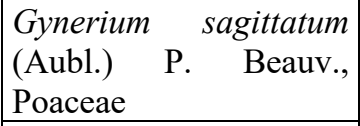 & Caña brava, 040671 & AP & The fresh exudate from the stem is drunk in the morning. (C) \\
\hline $\begin{array}{l}\text { Hura crepitans L., } \\
\text { Euphorbiaceae }\end{array}$ & $\begin{array}{l}\text { Catahua } \\
035787\end{array}$ & B & $\begin{array}{l}\text { The bark decoction is drunk against viral infections such as HIV } \\
\text { (once a day) but the treatment mustn't exceed one month, associated } \\
\text { with strict restrictions (food diet a , sexual abstinence), without sun } \\
\text { exposure (risk of blindness). (A) }\end{array}$ \\
\hline
\end{tabular}




\begin{tabular}{|c|c|c|c|}
\hline $\begin{array}{l}\text { Jatropha curcas L., } \\
\text { Euphorbiaceae }\end{array}$ & $\begin{array}{l}\text { Piñon blanco (yura } \\
\text { piñon), } 033695\end{array}$ & $\mathrm{~L}$ & $\begin{array}{l}\text { The sap is expressed from the leave, then diluted in water and drunk } \\
3 \text { times a day, with dietary restrictions }{ }^{\text {a }} \text {. (A) }\end{array}$ \\
\hline \begin{tabular}{|l|l|} 
Malachra ruderalis \\
Gürke, Malvaceae
\end{tabular} & $\begin{array}{ll}\text { Malva } \quad \text { (malwa) } \\
015674\end{array}$ & AP & $\begin{array}{l}\text { Infusion macerated all the night and drunk during the following day, } \\
\text { against digestive symptoms of hepatitis. (B) }\end{array}$ \\
\hline $\begin{array}{l}\begin{array}{l}\text { Mansoa alliacea }(\text { Lam. } \\
\text { A.H. } \\
\text { Bignoniaceae }\end{array} \\
\end{array}$ & $\begin{array}{l}\text { Ajo sacha, (ahu } \\
\text { sacha), } 035204\end{array}$ & $\mathrm{~L}$ & $\begin{array}{l}\text { 3-4 Leaves or bark decoction are drunk against viral infections (HIV, } \\
\text { hepatitis), with special food diet }{ }^{\mathrm{a}} \text {. (A) }\end{array}$ \\
\hline 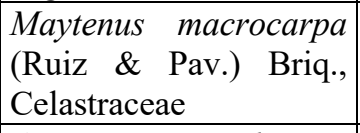 & $\begin{array}{ll}\text { Chuchu } & \text { washa, } \\
036978 & \end{array}$ & B & $\begin{array}{l}\text { Maceration in alcohol or decoction, drunk against viral infections } \\
\text { such as HIV, with dietary restrictions }{ }^{\text {a }} \text {. (A) }\end{array}$ \\
\hline \begin{tabular}{|l|} 
Oenocarpus bataua \\
Mart., Arecaceae
\end{tabular} & $\begin{array}{l}\text { Ungurahui, } \\
\text { (Unkurahui), } \\
\text { O33549 }\end{array}$ & $\begin{array}{l}\mathrm{Fr} \\
\mathrm{R}\end{array}$ & $\begin{array}{l}\text { Edible fruit are eaten during the food diet. } \\
\text { Heart of palm or roots are infused, then macerated all the night and } \\
\text { drunk during the following day, against digestive symptoms of } \\
\text { hepatitis. (C) }\end{array}$ \\
\hline $\begin{array}{l}\text { Persea americana Mill., } \\
\text { Lauraceae }\end{array}$ & Palta, 033683 & $\mathrm{~L}$ & 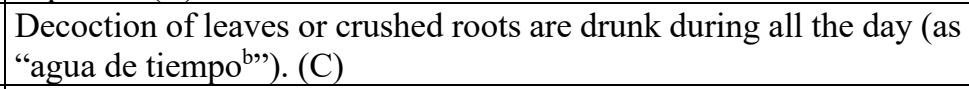 \\
\hline $\begin{array}{l}\text { Phyllanthus stipulatus } \\
\text { (Raf.) G.L. Webster, } \\
\text { Phyllanthaceae }\end{array}$ & $\begin{array}{l}\text { Chanca piedra (Aya } \\
\text { kiwa puca), } 041971\end{array}$ & $\begin{array}{l}\text { AP } \\
\mathrm{R}\end{array}$ & $\begin{array}{l}\text { Decoction of the whole crushed plant is drunk against hepatitis and } \\
\text { its digestive symptoms ( } 3 \text { times a day), with dietary restrictions }{ }^{\text {a }} \text {. (A) }\end{array}$ \\
\hline $\begin{array}{l}\text { Phyllanthus urinaria } \mathrm{L} ., \\
\text { Phyllanthaceae }\end{array}$ & $\begin{array}{l}\text { Chanca } \\
024633\end{array}$ & EP & Simi \\
\hline $\begin{array}{l}\text { Physalis angulata L., } \\
\text { Solanaceae }\end{array}$ & \begin{tabular}{|l|}
$\begin{array}{l}\text { Bolsa mulaca } \\
\text { (putiuntiu, mullaca), } \\
033878\end{array}$ \\
\end{tabular} & \begin{tabular}{|l|}
$\mathrm{AP}$ \\
$\pm \mathrm{GFr}$
\end{tabular} & $\begin{array}{l}\text { Roots and aerial parts decoction used to reduce symptoms of } \\
\text { hepatitis ( } 3 \text { times a day). (B) }\end{array}$ \\
\hline \begin{tabular}{|l|l|} 
Phytelephas & \\
macrocarpa Ruiz $\quad \&$ \\
Pav., Arecaceae
\end{tabular} & $\begin{array}{l}\text { Cabeza de mono, } \\
\text { yarina, } 026484\end{array}$ & $\mathrm{~L}$ & $\begin{array}{l}\text { or leaves are infused and drunk } 3 \text { times a day against } \\
\text { ptoms of hepatitis (with special diet }{ }^{\mathrm{a}} \text {, and avoiding sun } \\
\text { ) }\end{array}$ \\
\hline $\begin{array}{l}\text { Pouteria caimito (Ruiz } \\
\& \quad \text { Pav.) Radlk., } \\
\text { Sapotaceae }\end{array}$ & $\begin{array}{l}\text { Caimito, (apiyu } \\
\text { panka), } 033388\end{array}$ & L & $\begin{array}{l}\text { The ecoction of a handful of leaves in } 1 \mathrm{~L} \text { of water is drunk in the } \\
\text { morning during one week with strict restrictions (food diet a , and } \\
\text { sexual abstinence). (A) }\end{array}$ \\
\hline \begin{tabular}{|l|} 
Pseudelephantopus \\
spiralis $\quad$ (Less.) \\
Cronquist, Asteraceae \\
\end{tabular} & \begin{tabular}{|l|}
$\begin{array}{l}\text { Mata pasto } \\
\text { (millaypa } \\
\text { kiwa), } 033943\end{array}$ \\
\end{tabular} & AP & $\begin{array}{l}\text { Decoction of a handful of dried plant in } 1 \mathrm{~L} \text { of water. The preparation } \\
\text { is drunk } 2 \text { times a day until recovery. The treatment is associated } \\
\text { with dietary restrictions }{ }^{\text {a. }} \text { (A) }\end{array}$ \\
\hline $\begin{array}{l}\text { Scleria microcarpa } \\
\text { Nees ex Kunth, } \\
\text { Cyperaceae }\end{array}$ & $\begin{array}{l}\text { Cortadera (Chitiaru } \\
\text { kayu, kuchurikiwa), } \\
033427\end{array}$ & $\begin{array}{l}\text { AP } \\
\mathrm{R}\end{array}$ & $\begin{array}{l}\text { Root decoction of } 5 \text { roots in one litre of water is drunk during all the } \\
\text { day (as "agua de tiempo b") with dietary restrictions a }{ }^{\text {a }} \text { (C) }\end{array}$ \\
\hline $\begin{array}{ll}\text { Senna } & \text { reticulata } \\
\text { (Willd.) } & \text { H.S. Irwin \& } \\
\text { Barneby, Fabaceae }\end{array}$ & $\begin{array}{lr}\text { Retama } & \text { (Kucha } \\
\text { kaspi, aya } & \text { kaspi) } \\
035336 & \end{array}$ & $\begin{array}{l}\mathrm{Fl} \\
\mathrm{L}\end{array}$ & $\begin{array}{l}\text { The infusion of leaves is drunk during few days. } \\
\text { The infusion of flower (about } 4 \text { handfuls per litre of water) is drunk } \\
\text { alone or mixed with Curcuma longa (with special food diet }{ }^{\mathrm{a}} \text { ). } \\
\text { Used against hepatitis and associated symptoms (yellowing of eyes } \\
\text { and skin). (B) }\end{array}$ \\
\hline \begin{tabular}{|lrr} 
Socratea & exorrhiza \\
(Mart.) & H. & Wendl., \\
Arecacea & \\
\end{tabular} & \begin{tabular}{|lr} 
Casha & pona \\
(kawitu), & 033315
\end{tabular} & $\mathrm{~L}$ & Heart of palm are boiled and eaten every morning. (C) \\
\hline \begin{tabular}{|lr} 
Tessaria integrifolia \\
Ruiz \& Pav., Asteraceae
\end{tabular} & \begin{tabular}{|lr}
$\begin{array}{l}\text { Pájaro } \\
\text { (chillka), }\end{array}$ & b258bo \\
\end{tabular} & \begin{tabular}{|l|} 
AP \\
R
\end{tabular} & Infu \\
\hline $\begin{array}{l}\text { Urera baccifera (L.) } \\
\text { Gaudich. ex Wedd., } \\
\text { Urticaceae }\end{array}$ & $\begin{array}{l}\text { Lagarto } \\
\text { (lagartu } \\
039990\end{array}$ & AP & The infusion is drunk against digestive symptoms of hepatitis. (B) \\
\hline
\end{tabular}

AP: aerial parts, B: stem bark, Br: branch, EP: entire plant, Fr: fruit (G: green), HP: heart of palm (interior part of the trunk), L: leaves, R: root., NC: not classified (plant adulteration).

a Special diet: dietary restrictions without meat, fish, salt, spices, fat, sweet, alcohol, unpalatable foods.

b"Agua de tiempo": which means "water at any time", can be drunk all day long. 


\section{Ethnomedical study: The Amerindian situation with respect to illness and hepatitis}

Despite favourable weather conditions, the daily life reality of Amerindian people living in rainforests is often a perpetual fight for good health. In fact indigenous people suffer from many difficulties related to their particular environment, socioeconomic context, history, culture, or governmental disregard and social discrimination, which results in a reduction of their life expectancy (Montenegro and Stephens, 2006). This high mortality depends on various risk factors whose control could improve the management of diseases such as hepatitis as we described below:

\section{Physical and material factors:}

- Location of population. Geographic and rural isolation of indigenous communities contribute to increasing diseases morbidity by different ways: low access to health facilities (in case of emergency such as malaria crisis, ante/post-natal care, infected ascites due to hepatitis, etc.), lack of safe drinking water, dangerous work (woodcutting, hunting, fishing), hostile environments (predators, animal bites, drowning, wounds causing tetanus, mosquito or insect bites causing infections such as malaria), and other rural lifestyles that can expose populations to higher health risks. Solutions should consist in the development of transport logistics (boats with motors and fuel dedicated to emergencies) and protection devices (lyophilized antiserums, mosquito nets, clothing and safety equipment such as gloves and rubber boots).

- Evictions from ancestral lands. The Amerindian way of life is directly linked to their natural resources and this equilibrium can be destabilised by the intervention of modern society through oil or gas industries, dam or road building, woodcutting, trafficking in protected species, and other projects leading to the deforestation and dispossession of indigenous territories. In the oil concessions $1 \mathrm{AB} / 192$, including a part of the Pastaza river basin, the surface area deforested or covered by crude oil spills was estimated at 10 538 ha (Martínez et al., 2007). These environmental dislocations lead to brutal changes of daily life and disturb subsistence activities such as hunting, fishing, harvesting and collecting clean water from springs. It also weakens the indigenous cohesion and identity of the community. Moreover it deeply affects individual health with stress, diseases, hunger and poverty. It would seem important to moderate the external access to the rainforest and its exploitation.

- Material goods from modern society. Even though technology and new medications from the industrial world can be useful for indigenous communities, some imported goods remain deleterious for health e.g. fake or outdated medicines, strong spirit ("aguardiente", i.e. fermented juice of sugar cane), expired or "synthetic food" (freeze-dried milk), batteries and other harmful pollutants. Numerous cases of diseases due to the environmental impact of industries were reported in this area: acute cases of poisoning, cutaneous cancer, allergies, spontaneous abortions, malaria (due to the creation of large standing water basins leading to the proliferation of mosquitoes), leishmaniasis (because of proliferation of Phlebotominae in timber farms); this has contributed to increasing mortality in the neighbouring communities (Martínez et al., 2007; San Sebastián et al., 2001, 2002). Environmental exposure and human health parameters studied in the communities along the Pastaza river revealed high and toxic concentrations of mercury ( $41 \%$ of inhabitants with hair mercury level $>10 \mu \mathrm{g} / \mathrm{kg}$, and $4 \%$ of fish were considered as toxic with $[\mathrm{Hg}]>0.5 \mu \mathrm{g} / \mathrm{g}$ ). Similar results were obtained for barium, lead and chlorides as consequences of the petroleum exploitations (Webb and Mainville, 2009). It should be pointed out that an average of 2 spills a year are officially reported in Pastaza river, and that the high level of heavy metal contamination of the soils suggested other unreported leaks (OSINERG, 2007). Protection of these areas from foreign intrusion, and shifting of policies in the direction of environmental sustainability, with reparation of the past damages and prevention of further destructions, should be considered as parts of a reasonable health policy for these areas (e.g. water borehole drilling and water treatment systems). 
- Housing and living area. In the Amazonian communities, an indigenous family usually lives in the same house, in quite a limited area, and sometimes shares the same mosquito net during the night. This proximity can be reinforced during a travel, usually by boat, or a stay in town, and enhances the spread of contagious diseases. More resources could be given to local trainings on prevention in health and safety.

- Community infrastructure. Waste disposal (sludge, septic and solid waste), safeguard water resources, electricity for cold chains (permitting conservation of vaccines, venom antiserum, interferon against hepatitis), collective transport dedicated to emergency usually lacked in isolated areas, aggravating the impact of infectious diseases. Assistance for the development of these defective or nonexistent infrastructures is still lacking (only 1 motorised medical boat was available for 2-5 communities).

\section{Socio-cultural factors:}

- Children's schooling and health education. School or health and safety training are the initial steps for limiting the spread of illnesses, particularly for current contagious diseases such as syphilis, AIDS, hepatitis and tuberculosis. In remote villages or poor neighbourhoods, the language barrier and environmental hostility block the achievement of these pedagogic supports and contribute to worsening the health situation of these underprivileged areas. Intensive bilingual trainings at school on prevention in health would sustainably reduce the incidence of contagious diseases among the younger population.

- Cultural practices among Amerindian populations. Some particular cultural practices can enhance the likelihood of transmission of infectious diseases as hepatitis or exacerbate symptoms of illnesses, e.g. ways of feeding (without cutlery, irregular schedule and supply of food depending on weather conditions) or drinking (for instance "masato" is a usual Amazonian drink prepared from masticated manioc, usually mixed with water from the river, and distributed in the same cup to every visitor or members of a ceremony), delousing, sexual practices (sometimes polygamy), tattooing, piercing or lip perforations with unsterilized tools (Coimbra et al., 1996). This point highlights once again the need for bilingual trainings on prevention in health, with supplying of preventive goods like vitamin supplements, condoms, disinfectants etc.

- Cultural impact of modern society. Despite numerous projects for Amazonian conservation, and even thought traditional knowledge is cumulative and dynamic, the modern society contributes to accelerating the changing value, which implies a rapid loss of the "pre-existing know-how" and traditional therapies (Heinrich et al., 2009). Ethnographic surveys, especially those dedicated to ethnomedicine, ethnobotany, ethnoscience and other types of written testimonies or audio-video recordings are good ways to preserve traditional knowledge, especially when they are performed by the members of indigenous communities themselves.

- Employment or income. Indigenous citizens living near a city or an industrial establishment may have opportunities to get a paid work, but employment rates and incomes are usually lower for them than for unskilled workers (Rakibul and Mashhood, 2010). This disparity is all the more detrimental to these new employees as they live far from their plentiful forest, leading to gradual poverty and health decline. Moreover, numerous cases of prostitution and sexual abuse are observed for indigenous women living near such establishments, with introduction of new diseases by the foreign workers, e.g. HIV and hepatitis (Martínez et al., 2007). The compensation per indigenous employee should be normalized, avoiding any conflict of interest, and child prostitution or sexual abuse should be severely punished.

- Lack of data. Low access of health brigade and other assistance mandated for vaccination campaigns, disease eradication or prevention, epidemiologic survey, emphasised by cultural Amerindian specificities (e.g. poor written languages, absence of birth or death registrations, impossibility to gather all the members of a community) raise the difficulty of data compilation required for the improvement of health 
implementation plans. In this context, epidemiologic data on hepatitis are all the more incomplete as for this infectious disease the diagnosis assessment is logistically impossible and sick persons usually live in seclusion. New census campaigns aiming at completing national registrations and epidemiological data, with routine screening for viral diseases such as HIV and hepatitis, should be more widely undertaken.

\section{Physiological and medical factors:}

- Genetic determinism. Genetic and epigenetic heritage with poor diversity, due to the long-time isolation of these communities, makes these populations more sensitive to new diseases emerging from the modern society (e.g. viral or bacterial diseases like the flu or whooping cough were introduced by foreigners). Immunological studies exhibited the negative effects of homozygosity on health of Amerindians which are often infested with intestinal macroparasites. These chronical exposures lead to the overexpression of gene encoding for Ig,E, and results in a decrease of defence against other infections such as hepatitis (Salzano, 1990). Moreover, fieldwork data collection also showed that those isolated populations are more predisposed to develop side effects with some modern medication (intolerance or hyper-reactivity to vaccines, antibiotics, psychotropics), which can overcomplicate the cure of diseases (Hurtado et al., 2001). Epidemiological monitoring and research on indigenous susceptibility to drug and disease must be carefully considered and registered. Specific study of local iatrogenic effects and plant-drug interactions should require more attention from both researchers and medical staff.

- Discrepancy of healing concepts. Modern medicine is based on universal scientific practices adapted to large populations with standard ethical regulations, while traditional Amazonian medicines are influenced by various popular beliefs (here related to the animistic ontology, Descola, 2013; Luna, 1986) and depend on both practitioner and patient culture (Lévi-Strauss, 1949). In the case of the traditional medicine of Quechua people from Loreto, different aetiological categories of illnesses may be distinguished such as: "Unkuy", due to natural causes (excess of water, wind, heat...); "Pahu", relating to supernatural origins such as spirits from the forest; and "Wiruti" that referred to an invisible dart or a smoke blown by a shaman for therapy and sorcery in case of human conflicts (Roumy et al., 2007). The traditional curer can also include some "modern" aetiological factors such as the inter- or intra-specific contagiousness of diseases. In this context, modern medication is usually locally underestimated or proscribed and considered as primarily preventative, whereas traditional medicines are "curative". For example, administration of tablets and other pharmaceutical forms are often contraindicated with traditional medications and considered as ineffective against the aetiology of the disease. Compliance with prescriptions and medical advice must be explained and supervised while always considering possible interactions with local medicine.

These complex interactions between different medical systems may sometimes create a mutually beneficial relationship but also generate medical incompatibilities leading to the loss of medication compliance and treatment efficacy, especially for chronic diseases such as viral hepatitis.

\section{More specific factors affecting viral hepatitis:}

In case of hepatitis $\mathrm{B}$ or $\mathrm{C}$ in Amazonian communities, other aggravating factors of morbidity are present such as: the need for health centres or medical devices for diagnosis (the existing ones are far away and expensive), the non-assessment of vaccination due to the household head willing or for administrative reason (undocumented patient), the local unawareness of transmission routes, the cost and conservation of medication or vaccines, the non-respect of nutritional- hygienic precautions, the material or cultural incompatibilities with condom protection, etc. 
The clinical context is also a major determinant for the spread of disease. Healthy carriers may contaminate their relatives without wariness (Alberti et al., 1992). Patients with associated cutaneous infections are more likely to be contaminated by viral hepatitis $31.5 \%$ of inhabitants have dermatoses in Peruvian Amazon; Coimbra et al., 1996; Gutierrez et al., 2010). Clinical observations also exhibited that cumulated liver damages due to other diseases such as malaria and other parasitoses also exacerbated the hepatitis symptoms, and mutually, chronic viral hepatitis may be a risk factor for severe malaria (an overall prevalence of HBsAg of $23.8 \%$ have already been reported in Vietnamese patients hospitalized for malaria ; Barcus,et al., 2002). These factors and clinical data could be better controlled through bilingual trainings on transmission of viral infections in indigenous communities.

For all the above reasons or aggravating factors, and despite casual medical supports, hepatitis is still one of the first causes of illness and mortality in Amazonia. Nonetheless, this analysis of indigenous situation will permit a better adjustment of health strategy in these communities and other tropical areas. It also justified the ethnopharmacological work dedicated to the collect of cultural data for their preservation and the improvement of local treatments.

\section{Results of biological assays and interpretation.}

In vitro assays revealed interesting activities (> 50\% inhibition of $\mathrm{HCV}$ infection at $25 \mu \mathrm{g} / \mathrm{mL}$ ) for 18 plant extracts corresponding to 15 species: Bixa Orellana (L), Euterpe precatoria (R), Scleria microcarpa (R and AP), Astrocaryum jauari (R), Phyllanthus stipulatus (R and AP), Oenocarpus bataua (Fr), Cecropia ficifolia (L), Pouteria caimito (L), Persea americana (L), Physalis angulata (APGFr), Chamaesyce thymifolia (R and AP), Mansoa alliacea (EP), Maytenus macrocarpa (B), Curcuma longa (R), Caesalpinia pulcherrima (L). The same assays showed that 6 other extracts had low activities (30\% to $50 \%$ of $\mathrm{HCV}$ inhibition): Aspidosperma excelsum (B), Gossypium barbadense (Fl), Hura crepitans (B), Jatropha curcas (L), Malachra ruderalis (AP), Senna reticulata (F1) (see Table 2; Fig. 2). Moreover, the remedies from category A (preparations with low and accurate dosing as targeted therapy against hepatitis) were moderately more active than plants from categories B or C (80\% of activity, $>30 \%$ inhibition at $25 \mu \mathrm{g} / \mathrm{mL}$, for category A, instead of $37.5 \%$ or $47.1 \%$ for categories B or C), which attested the previous classification assumed in the ethnobotanical study (Fig. 3) and corroborated biological activities described in previous study for "teaching plants" from category A (Jauregui et al., 2011). Huh-7 cell nuclei number analysis showed that only 4 of the most active plants were also toxic on Huh-7 cells: Persea americana (L), Physalis angulata (APGFr), Curcuma longa (R) and Aspidosperma excelsum (B), which demonstrated a potential toxicity of these species. Nevertheless, this narrow therapeutic range did not forbid the use of species like Curcuma longa or Physalis angulata which have specific toxicity against hepatoma cell lines (HepG2 or Huh-7) without effects on healthy human cells (Salama et al., 2013). Moreover, cytotoxic assays realised on HepG2 cells (see Table 2), did not reveal important growth inhibitions except for Curcuma longa (as previously cited) and Aspidosperma excelsum (a species carefully used for the antimalarial activity of its indole alkaloids, and characterized by a moderate antiHCV activity).

\section{Discussion}

\section{Phytochemical analysis}


Bibliographical review exhibited less studies on anti-HCV plant properties than on anti-HBV. However, some publications related the antiviral activity of plant extracts and natural products extracted from plants on HCV in vitro (Séron et al 2018). These compounds target the different steps of the viral infectious cycle, entry, replication, cell-to-cell spread and assembly. Our groups have recently identified dehydrojuncusol from Juncus maritimus as a new inhibitor of HCV replication (Sahuc 2019). Interestingly, the target of the molecule is the viral NS5A protein, which is one of the main target of the drugs used in hepatitis $C$ therapy. In this study, some similarities were observed between plant extract already described in literature for their antiHBV activities, and plant extracts with anti-HCV capacity identified here (Phyllanthus spp, Euterpe precatoria, Curcuma longa are active against both hepatitis virus).

A search in the literature indicated that phytochemical antiviral agents of some of the 15 most active plants have already been characterized but the majority of them are unknown, as described below:

Bixa orellana (leaves): No antiviral activity had been reported, but antimicrobial terpenes and phenolics compounds have already been identified from leaves without observed toxicity (Stohs, 2014. Moreover, hepatoprotective activity had been characterized in rats with liver damage induced by $\mathrm{CCl}_{4}$ (Ahsan et al.,2009).

Euterpe precatoria (roots): Stem extract E. precatoria previously tested exerted a reduction in HBV replication at $100 \mathrm{mg} / \mathrm{mL}$ (measured by PCR, Quintero et al., 2011). Regarding the root of this species, antioxidant and hepatoprotective flavonoids (quercetin, catechin, epicatechin, rutin and astilbin) were isolated. Catechin, epicatechin and rutine did not show any activity against $\mathrm{HCV}$, whereas quercetin activity against $\mathrm{HBV}$ has already been described (partial inhibition of HBsAg secretion at $0.2 \mathrm{mmol} / \mathrm{mL}$, Galotta et al., 2008; Calland et al., 2012; Yang and Chen, 2008). Therefore, the presence of quercetin could partially explain anti-HCV activity observed for the root of this species.

Scleria microcarpa and Astrocaryum jauari: No previous data on compounds and biological activity of these plants have been published.

Phyllanthus stipulatus (roots or aerial parts): Despite absence of previous study of this species the genus Phyllanthus is one of the most active botanical group against viral hepatitis all over the world. Lignans and gallic derivatives isolated from various species of Phyllanthus (P. amarus, P. multiflorus, $P$. tenellus, $P$. virgatus) were characterized by anti-HBV activities. Other previous study showed that Phyllanthus urinaria grown in different areas in China exhibited different antiHBV activity, nonetheless this species is now commercially produced in China for clinical use (Huang et al., 2003). Additionally, liquid chromatography coupled to mass spectrometry (LCIT-MS ${ }^{\mathrm{n}}$ ) of P. stipulatus showed presence of phenolic compounds as quercetin and gallic acid derivatives potentially involved in anti-HCV and antioxidant activities (Da Fontoura Sprenger and Cass, 2013).

Oenocarpus bataua (fruits): Antioxidant phenolic compounds have been identified using UPLCAPI-IT-MS ${ }^{n}$ (stilbenes, hydroxycinnamic acid, procyanidin and anthocyanin derivatives) but anti-HCV activity has never been described before (Rezaire et al., 2014). 
Cecropia ficifolia (leaves): This species has never been studied for its chemical compounds or biological activity but other species of the genus Cecropia (C. palmata and C. obtusa leaves) have been described to contain anti-HCV triterpenic compounds as oleanolic acid (Schmidt et al., 2018; Kong et al., 2013).

Pouteria caimito (leaves): Antioxydant proanthocyanidin and anti-inflammatory terpenes (spinasterol) have already been identified in leave extract, but no antiviral activity has been mentioned before (França et al., 2016).

Persea americana (leaves): Antiviral activity of the infusion of $P$. americana leaves against herpes simplex virus (HSV-1), adenovirus (AD3...), and human immunodeficiency virus 1 (HIV-1) have been previously reported, and may be induced by synergistic effect between flavonoids, chlorogenic acid, and other unidentified compounds (De Almeida et al., 1998; Wigg et al., 1996). Nevertheless, the leave extract toxicity observed in this study was also previously demonstrated on livestock and mice (on myocardium or mammary gland, at $60-100 \mathrm{mg} / \mathrm{kg}$ and caused by the fatty acid "persin"), prohibiting the use of this plant by pregnant/nursing woman and patients with heart weakness (Oelrichs et al., 1995).

Physalis angulata (aerial parts with green fruits): No previous study reported antiviral activity of this plant species. Even if cytotoxicity was observed in this screening on HepG2 cells, previous data showed that cytotoxic effect did not affect normal mouse liver cells. Furthermore, hydroethanolic extract has been shown to possess potent anti-inflammatory and anti-hepatoma activities due to steroid compounds as physalins, and flavonol glycosides such as myricetin derivatives (Wu et al., 2004; Chiang et al., 1992; Ismail and Alam, M. 2001).

Chamaesyce thymifolia (roots or aerial parts): Moderate antiviral activity on HSV-1 and bovine viral diarrhea virus (BVDV) with low selectivity has been described for phenolic compounds (quercetin and galloyl esters of glucose derivatives) isolated from the aerial parts, but antiviral activity against hepatic viruses has never been studied (Amaral et al., 1999; Lin et al., 2002). Even if anti-inflammatory and hepatoprotective activities have been characterized for this species, dermatotoxicity (due to phorbol derivatives) and low selectivity observed for this plant do not allow chronic or important use of this remedy (Mali and Panchal, 2013; Muthumani et al., 2016).

Mansoa alliacea (entire plant): Even if this well-known traditional remedy is rich in organosulfur compounds with anti-inflammatory and anti-infectious properties, its organoleptic properties and its cytotoxic naphthoquinones may limit the recommended dosage (Itokawa et al., 1992; Pires et al., 2016; Towne et al., 2015).

Maytenus macrocarpa (bark): Terpenic derivatives from the leaves (di and triterpens) exhibited marginal cytotoxic activity and antiviral activity against HIV (triterpenonic acids), but no antiviral activity against hepatic viruses has already been published (Chavez et al., 1999; Piacente et al., 2006).

Curcuma longa (roots): The polyphenolic compound "curcumin" has been shown to inhibit HCV entry and replication, and HBV replication, and is considered to be a potentially important 
chemo-preventive agent against a variety of cancers, including liver cancer, without observed toxicity (Kim et al., 2010; Salama et al., 2013). This study and previous data demonstrated that Curcuma longa could be used as a complementary therapy for HCV, while considering low oral bioavailability of curcumin, it should be administered with piperin (from Pieraceae or other botanical families; Shoba et al., 1998).

Caesalpinia pulcherrima (leaves): Quercetin flavonoids and isoflavons were responsible of antiinflammatory and antiviral activities (against HSV or adenovirus), but no previous data were recorded on hepatic viruses (Akram et al., 2018; Chiang et al., 2003). Nonetheless, a slight toxicity on brine shrimp had been reported $\left(26 \%\right.$ mortality at $\left.1000 \mu \mathrm{g} \mathrm{mL} \mathrm{m}^{-1}\right)$, that could limit the recommended dosage for pregnant women or young children (Chanda and Baravalia, 2011; Rao et al., 2005).

The drug extracts characterized by lower anti-HCV activity than species mentioned above may have other interests against hepatitis. For instance, they may be efficient against other hepatitis viruses (non-evaluated in this study) or may reduce liver degeneration and fibrosis, thereby contributing to alleviate hepatitis disease as observed for the biological activities of species cited below:

- Anti-oxidant and/or anti-inflammatory properties: Crescentia cujetes (Parvin et al., 2015), Eryngium foetidum (Paul et al., 2011), Jatropha curcas Leaves (Thomas et al., 2008), Senna reticulata (Navarro et al., 2017), Tessaria integrifolia (Peluso et al., 1995), Urera baccifera (Gindri et al., 2014).

- Hepatoprotective activities: Desmodium adscendens (François et al., 2015), Cajanaus cajan (Ahsan et al., 2009), Carica papaya (leaf and seed: Pandit et al., 2013; Adeneye et al., 2009).

- And other pathway as fighting hepatitis symptoms (diuretic against ascites, choleretic against icterus, digestive ...) or improving bioavailability of antiviral remedies.

Nonetheless, some of the selected species have previous toxicological reports that could contraindicate their dispensation for chronic use in case of pregnancy or childhood:

Carica papaya: Seeds extract caused concentration-dependent tocolysis of uterine strips rats (Adebiyi et al., 2003).

Aspidosperma excelsum: Toxicity of the bark methanolic and dichloro-methane extracts were observed on brine shrimp (LC50: 764 and $85 \mu \mathrm{g} / \mathrm{mL}$, Desmarchelier et al., 1996).

Gynerium sagittatum: The high content of isoflavonoids makes this plant root an important source of phytoestrogen that could contraindicated the chronic use of the plant in case of pregnancy (Benavides et al., 2007).

Jatropha curcas: Leaf extract exerted cardiovascular effects (beta-blockers) on guinea pigs. Moreover, the presence of the toxin toxalbumin (curcin) may contraindicate a chronic use of this plant by pregnant women or young children (Thomas et al., 2008).

Pseudelephantopus spiralis: An important cytotoxicity of leaf extract has already been described on VERO cells and macrophage $\left(\mathrm{CC}_{50}: 1-5 \mu \mathrm{g} / \mathrm{mL}\right)$ and may contraindicate its chronic use (Girardi et al., 2015).

Socratea exorrhiza: The leaf extract cytotoxicity evaluated in this study on HepG2 cells (IC 50 : $39.3 \pm 18.3 \mu \mathrm{g} / \mathrm{mL}$ ) highlighted potential side effects of this drug in chronic use. 
Fig. 2: Antiviral activity of plant extracts (HCV inhibition $>30 \%$ at $25 \mu \mathrm{g} / \mathrm{mL}$ ) and cytotoxicity ( $\%$ of viability at $25 \mu \mathrm{g} / \mathrm{mL}$ )

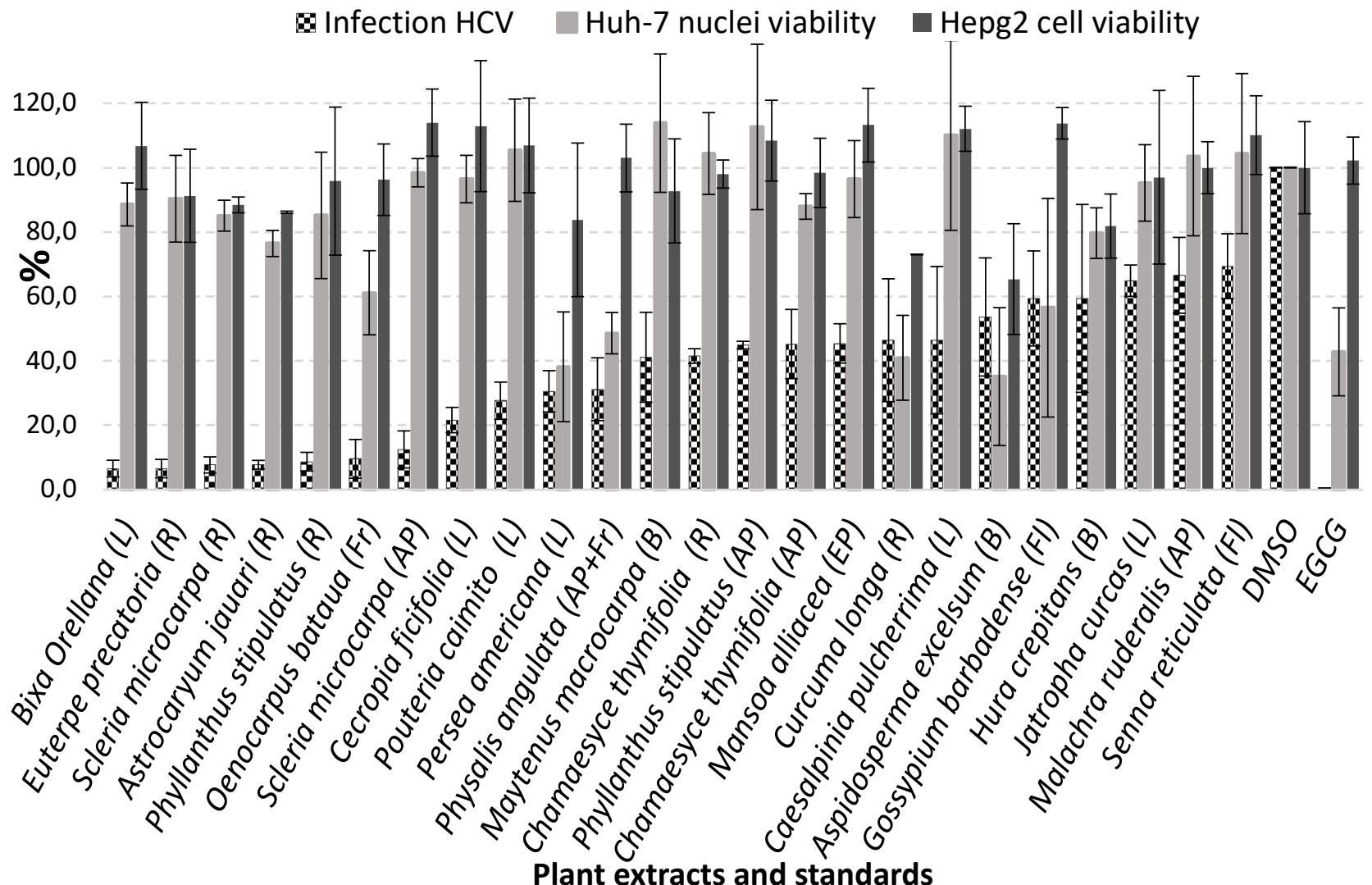

Fig. 3 Anti HCV activity at $25 \mu \mathrm{g} / \mathrm{mL}$ (>30\% infection inhibition) and its repartition by drug

category

Antiviral activty

(> $30 \%$ inhibition at 25

$\mu \mathrm{g} / \mathrm{mL}$ )

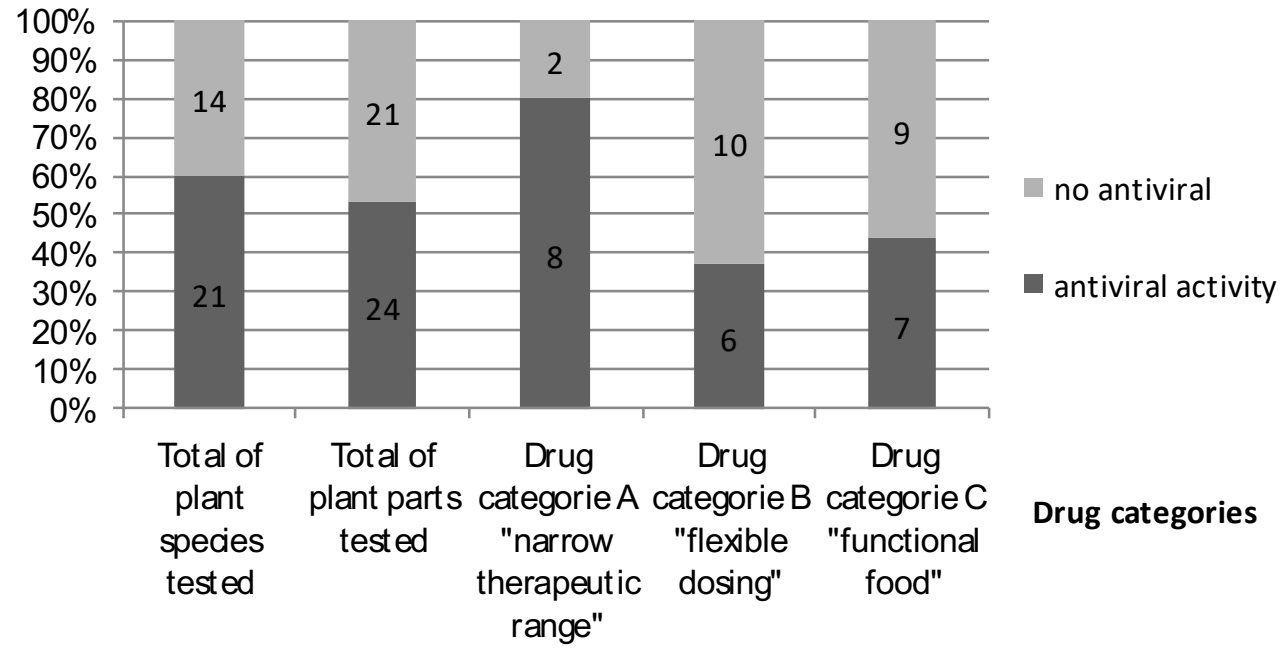




\section{Conclusion}

This study exposed the results of a bioprospecting leading to the collect and identification of 35 plants with assessment of their antiviral or cytotoxic activities, and may contribute, with the ethnomedical analysis of indigenous situation, to a better adjustment of the health strategy against hepatitis in Peruvian Amazon.

45 plant extracts were tested for antiviral activity against HCV with counting of cellular death in case of toxicity and cytotoxicity evaluation in HepG2 cells. In vitro assay revealed interesting activity of 18 extracts ( $>50 \%$ infection inhibition at $25 \mu \mathrm{g} / \mathrm{mL}$ ) with a selectivity index $>2$ for 15 of them. Lower antiviral activities were also observed for 6 other drug extracts $(30 \%$ to $50 \%$ infection inhibition at $25 \mu \mathrm{g} / \mathrm{mL}$ ).

Result analysis showed an interesting global level of activity ( $60 \%$ of plant extract inhibited more than $30 \%$ of $\mathrm{HCV}$ virus at $25 \mu \mathrm{g} / \mathrm{mL}$ ). This supported the traditional medicinal uses of these plants and highlighted the relevance of the ethnobotanical approach. Moreover, drugs from the category A were more active against $\mathrm{HCV}$ than plants from categories $\mathrm{B}$ or $\mathrm{C}$, that reinforced the tripartite drug classification assumed during the survey, and permitted to justify the cautious but efficient use of these plants against viral hepatitis. Nonetheless, drugs from other categories (B or C) may also occasionally have anti-HCV activities and are still helpful to prevent collateral effects of hepatitis.

On the other hand, bibliographical report and cytotoxicity evaluations permitted to refine the therapeutic indications regarding to patient's vulnerability (in case of pregnancy or childhood), specially for Socratea exorrhiza leaves and Gynerium sagittatum aerial parts, which were usually indicated for daily use (category C) whereas potential toxicity had been characterized. The bibliographic study of the 15 most active plants ( $>50 \%$ inhibition at $25 \mu \mathrm{g} / \mathrm{mL}$ ) also indicated that only 2 of them have already been studied for antiviral activity against hepatitis (Curcuma longa and Socratea exorrhiza), suggesting new avenues to be followed for the 13 other species. More generally, these results will permit to improve the medical administration of the different plant species regarding their traditional uses and considering their antiviral or cytotoxic activities, with a better understanding of their preparation and posology in case of acute hepatitis (punctual administration), liver dysfunctions (regular treatment), or incorporated in a diary food diet against digestive troubles.

\section{Conflict of interest}

The authors declare that they have no conflict of interest.

\section{Acknowledgements}

Members and contributors of the scientific humanitarian association ARPIA (Association for Research on Indigenous Amazonian Pharmacopeia); F.M. Lambert (Commission du Développement durable et de l'Aménagement du territoire); CPER Alibiotech; C. Mori and C. 
Güivinsinti; Luis and Aurelio Chino (presidents of Indigenous Quechua Federations), the members of Quechua community "Sabalo Yacu" who contributed to the building of a traditional medical centre in the Alto Pastaza.

\section{References}

Adebiyi, A., Adaikan, P.G., Prasad, R.N.V. 2003. Tocolytic and toxic activity of papaya seed extract on isolated rat uterus. Life Sci., 74, 581-592, https://doi.org/10.1016/j.lfs.2003.06.035.

Adeneye, A.A., Olagunju, J.A., Banjo, A.A.F., Abdul, S.F., Sanusi, O.A., Sanni, O.O. 2009. The aqueous seed extract of Carica papaya Linn. prevents carbon tetrachloride induced hepatotoxicity in rats. Int. J. Appl. Res. Nat. Prod. 2, 19-32. http://www.healthy-synergies.com.

Ahsan, R., Islam, K.M., Musaddik, A., Haque, E. 2009. Hepatoprotective activity of methanol extract of some medicinal plants against carbon tetrachloride induced hepatotoxicity in albino

$\begin{array}{llllll}\text { rats. } & \text { Eur. } & \text { J. } & \text { Sci. } & \text { Res. } & 37,\end{array}$ https://pdfs.semanticscholar.org/c84e/d128c933f8a826d4c00f457c480e62c5f301.

Akram, M., Tahir, I. M., Shah, S. M. A., Mahmood, Z., Altaf, A., Ahmad, K. 2018. Antiviral potential of medicinal plants against HIV, HSV, influenza, hepatitis, and coxsackievirus: a systematic review. Phytother. Res. 32, 811-822. https://doi.org/10.1002/ptr.6024.

Alberti, A., Morsica, G., Chemello, L., Cavalletto, D., Noventa, F., Pontisso, P., Ruol, A. 1992. Hepatitis $\mathrm{C}$ viraemia and liver disease in symptom-free individuals with anti-HCV. The Lancet, 340, 697-698. https://doi.org/10.1016/0140-6736(92)92234-7.

Amaral, A.C.F., Kuster, R.M., Gonçalves, J.L.S., Wigg, M.D. 1999. Antiviral investigation on the flavonoids of Chamaesyce thymifolia. Fitoterapia. 70, 293-295, https://doi.org/10.1016/S0367326X(99)00008-8.

Anggakusuma, Colpitts, C.C., Schang, L.M., Rachmawati, H., Frentzen, A., Pfaender, S., Behrendt, P., Brown, R.J.P., Bankwitz D., Steinmann, J., Ott, M., Meuleman P., Rice C.M., Ploss, A., Pietschmann, T., Steinmann, E. 2014. Turmeric curcumin inhibits entry of all hepatitis $C$ virus genotypes into human liver cells. Gut. 63. 1137-49. https://doi.org/10.1136/gutjnl-2012- 304299.

Bachmetov, L., Gal-Tanamy, M., Shapira, A., Vorobeychik, M., Giterman-Galam, T., Sathiyamoorthy, P., Golan-Goldhirsh, A., Benhar, I., Tur-Kaspa, R., Zemel, R. 2012. Suppression of hepatitis C virus by the flavonoid quercetin is mediated by inhibition of NS3 protease activity. J. Viral. Hepat. 19, 81-88. https://doi.org/10.1111/j.1365-2893.2011.01507.x.

Barcus, M.J., Hien, T.T., White, N.J., Laras, K., Farrar, J., Schwartz, I.K, Corwin A., Baird, J.K. 2002. Hepatitis B infection and severe Plasmodium falciparum malaria in Vietnamese adults. Am. J. Trop. Med. Hyg.,66, 2002, 140-14. https://doi.org/10.4269/ajtmh.2002.66.140.

Benavides, A., Bassarello, C., Montoro, P., Vilegas, W., Piacente, S., Pizza, C. 2007. Flavonoids and isoflavonoids from Gynerium sagittatum. Phytochemistry. 68, 1277-1284. https://doi.org/10.1016/j.phytochem.2007.03.007. 
Calland, N., Albecka, A., Belouzard, S., Wychowski, C., Duverlie, G., Descamps, V., Hober, D., Dubuisson, J., Rouillé, Y., Séron, K. 2012. (-)-Epigallocatechin-3-gallate is a new inhibitor of hepatitis C virus entry. Hepatology, 55, 720-729. https://doi.org/10.1002/hep.24803.

Calland N, Sahuc M-E, Belouzard S, Pène V, Bonnafous P, Mesalam AA, Deloison, G., Descamps, V., Sahpaz, S., Wychowski, C., Lambert, O., Brodin, P., Duverlie, G., Meuleman, P., Rosenberg, A. R., Dubuisson, J., Rouillé Y., Séron, K. 2015. Polyphenols Inhibit Hepatitis C Virus Entry by a New Mechanism of Action. J. Virol. 89, 10053-10063. https://doi.org/10.1128/JVI.01473-15.

Carrat, F., Fontaine, H., Dorival, C., Simony, M., Diallo, A., Hezode, C., 2019. Clinical outcomes in patients with chronic hepatitis $\mathrm{C}$ after direct-acting antiviral treatment: a prospective cohort study. The Lancet, 393, 1453-1464. https://doi.org/10.1016/S0140-6736(18)32111-1.

Chanda, S., Baravalia, Y. 2011. Brine shrimp cytotoxicity of Caesalpinia pulcherrima aerial parts, antimicrobial activity and characterisation of isolated active fractions. Nat. Prod. Res. 25, 1955-1964. https://doi.org/10.1080/14786419.2010.530600

Chavez, H., Callo, N., Estevez-Braun, A., Ravelo, A.G., Gonzalez, A.G. 1999. Sesquiterpene polyol esters from the leaves of Maytenus macrocarpa. J. Nat. Prod., 62, 1576-1577. https://doi.org/10.1021/np990232f.

Chen, M.H., Lee, M.Y., Chuang, J.J., Li, Y.Z., Ning, S.T., Chen, J.C., \& Liu, Y.W. 2012. Curcumin inhibits HCV replication by induction of heme oxygenase-1 and suppression of AKT. Int. J. Mol. Med. 30, 1021-1028. https://doi.org/10.3892/ijmm.2012.1096.

Chiang, H.C., Jaw, S.M., Chen, C.F., Kan, W.S. 1992. Antitumor agent, physalin F from Physalis angulata $\mathrm{L}$. Anticancer Res. 12, 837-843. https://europepmc.org/med/1622143.

Chiang, L.C., Chiang, W., Liu, M.C., Lin, C.C. 2003. In vitro antiviral activities of Caesalpinia pulcherrima and its related flavonoids. J. Antimicrob. Chemother. 52, 194-198. https://doi.org/10.1093/jac/dkg291.

Chung, C.Y., Liu, C.H, Burnouf, T., Wang, G.H., Chang S.P., Jassey, A., Tai, C.J., Tai C.J., Huang C.J., Richardson, C.D., Yen, M.H., Lin, C.C., Lin, L.T. 2016. Activity-based and fraction- guided analysis of Phyllanthus urinaria identifies loliolide as a potent inhibitor of hepatitis $\mathrm{C}$ virus entry. Antiviral Res. 130. 58-68. https://doi.org/10.1016/j.antiviral.2016.03.012.

Coimbra C.E.A., Santos R.V., Yoshida, C.F.Y., Baptista M.L., Flowers N.M. Carlos A., Do Valle, F. 1996. Hepatitis B epidemiology and cultural practices in Amerindian populations of

amazonia: the tupi-mondé and the xavante from Brazil. Soc. Sci. Med. 42, 1738-1743. https://doi.org/10.1016/0277-9536(95)00295-2.

Da Fontoura Sprenger, R., Cass, Q.B. 2013. Characterization of four Phyllanthus species using liquid chromatography coupled to tandem mass spectrometry. J. Chromatogr. A. 1291, 97-103, https://doi.org/10.1016/j.chroma.2013.03.030.

De Almeida, A.P., Miranda, M.M., Simoni, I.C., Wigg, M.D., Lagrota, M.H., Costa, S.S. 1998. Flavonol monoglycosides isolated from the antiviral fractions of Persea americana (Lauraceae) leaf infusion. Phytother. Res., 12, 562-567. https://doi.org/10.1002/(SICI)1099- 73(199812)12:8<562::AIDPTR356>3.0.CO;2-6. 
Delgrange, D., Pillez, A., Castelain, S., Cocquerel, L., Rouillé, Y., Dubuisson, J., Wakita, T., Duverlie, G., Wychowski, C. 2007. Robust production of infectious viral particles in Huh-7 cells by introducing mutations in hepatitis $\mathrm{C}$ virus structural proteins. J. Gen. Virol. 88, 2495-2503. https://doi.org/10.1099/vir.0.82872-0.

Descola, P. Beyond nature and culture. 2013. University of Chicago Press. Chicago.

Desmarchelier, C., Mongelli, E., Coussio, J., Ciccia, G. 1996. Studies on the cytotoxicity, antimicrobial and DNA-binding activities of plants used by the Ese'ejas. J. Ethnopharmacol. 50, 91-96. https://doi.org/10.1016/0378-8741(95)01334-2.

Duke, J.A.V., Vasquez, R., 1994. Amazonian ethnobotanical dictionary. CRC press, Boca Raton.

FORMABIAP (Programa de Formación de Maestros Bilingües de la Amazonía Peruana), AIDESEP (Asociación Interétnica de Desarrollo de la Selva Peruana). 2008. La vida secreta de las plantas medicinales en los pueblos kichwa, kukama-kukamiria y tikuna. Nouvelle Planète. Iquitos.

França, C.V., Perfeito, J.P.S., Resck, I.S., Gomes, S.M., William, C., Fagg, C.F.S.C. 2016. Potential radical-scavenging activity of Pouteria caimito leaves extracts. J. Appl. Pharm. Sci. 6, 184-188. http://www.japsonline.com

François, C., Fares, M., Baiocchi, C., Maixent, J.M. 2015. Safety of Desmodium adscendens extract on hepatocytes and renal cells. Protective effect against oxidative stress. J. Intercult. Ethnopharmacol. 4, 15. https://doi.org/10.5455/jice.20141013041312.

Galotta, A.L.Q.A., Boaventura, M.A.D., Luciana, L.A.R.S. 2008. Antioxidant and cytotoxic activities of 'açaí' (Euterpe precatoria Mart.). Quim. Nova, 31, 1427-1430. https://dx.doi.org/10.1590/S010040422008000600028.

Germaná C., Lozano L. 2013. 10 years in the Abanico del Pastaza, nature, cultures and challenges in the Northern Peruvian Amazon, WWF, Lima.

Gindri, A.L., De Souza, L.B., Cruz, R.C., Boligon, A.A.,, Machado, M.M., Athayde, M.L. 2014. Genotoxic evaluation, secondary metabolites and antioxidant capacity of leaves and roots of Urera baccifera Gaudich (Urticaceae), Nat. Prod. Res. 28, 2214-2216. https://doi.org/10.1080/14786419.2014.920333.

Girardi, C., Fabre, N., Paloque, L., Pramundita Ramadani, A., Benoit-Vical, F., González- Aspajo, G. 2015. Evaluation of antiplasmodial and antileishmanial activities of herbal medicine Pseudelephantopus spiralis (Less.) Cronquist and isolated hirsutinolide-type sesquiterpenoids. J. Ethnopharmacol. 170, 167174. https://doi.org/10.1016/j.jep.2015.05.014.

Goueslain, L., Alsaleh, K., Horellou, P., Roingeard, P., Descamps, V., Duverlie, G., Ciczora, Y., Wychowski, C., Dubuisson, J., Rouillé, Y. 2010. Identification of GBF1 as a cellular factor Rrequired for Hepatitis C virus RNA replication. J. Virol. 84, 773-787. https://doi.org/10.1128/JVI.01190-09.

Gutierrez, E.L., Galarza, C., Ramos, W., Tello, M., Jiménez, G., Ronceros, G., Chıa, H.J., Hurtado, J., Ortega-Loayza, A.G. 2010. Skin diseases in the Peruvian Amazonia. Int. J. Dermatol. 49, 794-800. https://doi.org/10.1111/j.1365-4632.2010.04473. 
Heinrich, M., Edwards., S., Moerman., D.E., Leonti., M. 2009. Ethnopharmacological field studies: a critical assessment of their conceptual basis and methods. J. Ethnopharmacol, 124, 1- 17. https://doi.org/10.1016/j.jep.2009.03.043.

Heinrich, M., Lardos, A., Leonti, M., Weckerle, C., Willcox, M. 2018. Best practice in research: consensus statement on ethnopharmacological field studies-ConSEFS. J. Ethnopharmacol. 211, 329-339. https://doi.org/10.1016/j.jep.2017.08.015

Huang, R., Huang, Y., Ou, J., Chen, C., Hsu, F., Chang, C. 2003. Screening of 25 compounds isolated from Phyllanthus species for anti-human hepatitis B virus in vitro. Phytother. Res. 17, 449-453. https://doi.org/10.1002/ptr.1167.

Hurtado, M., Hill, K., Kaplan, H., Lancaster, J. 2001. The epidemiology of infectious diseases among South American Indians: a call for guidelines for ethical research. Curr. Anthropol. 42, 425-432. https://doi.org/10.1086/320482.

Ismail, N., Alam, M. 2001. A novel cytotoxic flavonoid glycoside from Physalis angulata. Fitoterapia, 72, 676-679, https://doi.org/10.1016/S0367-326X(01)00281-7.

Itokawa, H., Matsumoto, K., Morita, H., Takeya, K. 1992. Cytotoxic naphthoquinones from Mansoa alliacea. Phytochemistry. 31, 1061-1062. https://doi.org/10.1016/0031-9422(92)80077- R.

Jauregui, X., Clavo, Z.M., Jovel, E.M., Pardo-de-Santayana, M., 2011. "Plantas con madre". Plants that teach and guide in the shamanic initiation process in the East-Central Peruvian Amazon, J. Ethnopharmacol. 134, 739-752. https://doi.org/10.1016/j.jep.2011.01.042.

Khachatoorian, R., Arumugaswami, V., Raychaudhuri, S., Yeh, G., Maloney, E.M., Wang, J., Dasgupta, A., French, S. 2012. Divergent antiviral effects of bioflavonoids on the hepatitis C virus life cycle. Virology. 433, 346-355. https://doi.org/10.1016/j.virol.2012.08.029.

Kim, K., Kim, K.H., Kim, H.Y., Cho, H.K., Sakamoto, N., Cheong, J. 2010. Curcumin inhibits hepatitis $\mathrm{C}$ virus replication via suppressing the Akt-SREBP-1 pathway. FEBS Lett. 584, 707- 712. https://doi: 10.1016/j.febslet.2009.12.019.

Kong, L., Li, S., Liao, Q., Zhang, Y., Sun, R., Zhu, X. 2013. Oleanolic acid and ursolic acid: Novel hepatitis $\mathrm{C}$ virus antivirals that inhibit NS5B activity. Antiviral Res. 98, 44-53. https://doi.org/10.1016/j.antiviral.2013.02.003.

Lévi-Strauss, C. 1949. L'efficacité symbolique. Revue de l'histoire des religions. 135, 5-27. https://www.jstor.org/stable/23665587.

Lin, C.C., Cheng, H.Y., Yang, C.M., Lin, T.C. 2002. Antioxidant and antiviral activities of Euphorbia thymifolia L. J. Biomed. Sci. 9, 656-664. https://doi.org/10.1159/000067281.

Lin, Y.T., Wu, Y.H., Tseng, C.K., Lin, C.K., Chen, W.C., Hsu, Y.C., Lee, J.C. 2013. Green Tea phenolic epicatechins inhibit Hepatitis $\mathrm{C}$ Virus replication via Cycloxygenase-2 and attenuate virus-induced inflammation. PLoS ONE. 8, 1-10. https://doi.org/10.1371/journal.pone.0054466.

Luna, L.E., 1986. Vegetalismo: Shamanism among the Mixed-blood native people Population of the Peruvian Amazon. Almqvist \& Wiksell International. Stockholm. 
Mali, P.Y., Panchal, S.S. 2013. A review on phyto-pharmacological potentials of Euphorbia thymifolia L. Anc. Sci. Life. 32, 165-72. https://doi.org/10.4103/0257-7941.123001.

Martínez, M.O., Napolitano, D.A., MacLennan, G.J., O’Callaghan, C., Ciborowski, S., Fabregas, X. 2007. Impacts of petroleum activities for the Achuar people of the Peruvian Amazon: summary of existing evidence and research gaps. Environ. Res. Lett., 2. https://doi.org/10.1088/1748-9326/2/4/045006

Mejia, K., Rengifo, E., 2000. Plantas medicinales de uso popular en la Amazonia Peruana. Second ed. Tarea asociación grafica educativa, Lima.

MINSA (Ministerio de Salud). Centro Nacional de Epidemiologia, Prevención y Control de Enfermedades, hepatitis C. 2018. Gobierno del Perú, Lima.

Montenegro, R. A., Stephens, C. Indigenous health in Latin America and the Caribbean, 2006. The Lancet. 367, 1859-1869. https://doi.org/10.1016/S0140-6736(06)68808-9.

Murphy Cowan, M., 1999. Plant Products as Antimicrobial Agents. Clin. Microbiol. Rev. 12, 564-582. http://cmr.asm.org/content/12/4/564.

Muthumani, D., Hedina, A., Kausar, J., Anand, V. 2016. Phytopharmacological activities of Euphorbia thymifolia Linn. Sys. Rev. Pharm. 7, 30-34. https://doi.org/10.5530/sip.2016.7.4

Navarro, M., Moreira, I., Arnaez, E., Quesada, S., Azofeifa, G., Alvarado, D. 2017. Proanthocyanidin characterization, antioxidant and cytotoxic activities of three plants commonly used in traditional medicine in Costa Rica: Petiveria alliaceae L., Phyllanthus niruri L. and Senna reticulata Willd. Plants, 6, 50. https://doi.org/10.3390/plants6040050.

Oelrichs, P.B., Ng, J.C., Seawright, A.A., Ward, A., Schäffeler, L., Macleod, J.K. 1995. Isolation and identification of a compound from avocado (Persea americana) leaves which causes necrosis of the acinar epithelium of the lactating mammary gland and the myocardium. Nat. Toxins, 3, 344-349. https://doi.org/10.1002/nt.2620030504.

OSINERG (Organismo Supervisor de la Inversión en Energía y Minería), 2007. Derrames reportados: 1998-2006: informes preliminares de derrame o fuga de petr oleo crudo o derivados, remitidos por OxyPer'u y Pluspetrol del Norte S.A. a OSINERG durante el perí odo 1998-2002.

PAHO (Pan American Health Organization). Hepatitis B and C in the Spotlight. A public health response in the Americas, 2016. PAHO HQ Library, Washington.

Pandit, A., Sachdeva, T., Bafna, P. 2013. Ameliorative effect of leaves of Carica papaya in ethanol and antitubercular drug induced hepatotoxicity. British J. Pharma. Res. 3, 648-661. https://doi.org/10.9734/BJPR/2014/4517.

Parvin, M.S., Das, N., Jahan, N., Akhter, M.A., Nahar, L., Islam, M.E. 2015. Evaluation of in vitro antiinflammatory and antibacterial potential of Crescentia cujete leaves and stem bark. BMC Res. Notes. 8, 412. https://doi.org/10.1186/s13104-015-1384-5.

Paul, J.H., Seaforth, C.E., Tikasingh, T. 2011. Eryngium foetidum L.: A review, Fitoterapia. 82, 302-308. https://doi.org/10.1016/j.fitote.2010.11.010. 
Peluso, G., De Feo, V., De Simone, F., Bresciano, E., Vuotto, M.L. 1995. Studies on the inhibitory effects of caffeoylquinic acids on monocyte migration and superoxide ion production. J. Nat. Prod. 58, 639-646. https://doi.org/10.1021/np50119a001.

Petruzziello, A., Marigliano, S., Loquercio, G., Cozzolino, A., Cacciapuoti, C. 2016. Global epidemiology of hepatitis $\mathrm{C}$ virus infection: an update of the distribution and circulation of hepatitis $\mathrm{C}$ virus genotypes. World J. Gastroenterol. 22, 7824-7840. https://doi.org/10.3748/wjg.v22.i34.7824.

Piacente, S., Santos, L.C.D., Mahmood, N., Pizza, C. 2006. Triterpenes from Maytenus macrocarpa and evaluation of their anti-HIV activity. Nat. Prod. Commun. 1, 1073-1078. https://doi.org/10.1177/1934578X0600101201.

Pires, F.B., Dolwitsch, C.B., Dal Prá, V., Monego, D.L., Maria, V., Schneider, R.F.L. 2016. An overview about the chemical composition and biological activity of medicinal species found in the Brazilian Amazon. J. App. Pharm. Sci. 6, 233-238. https://doi.org/10.7324/JAPS.2016.601234.

Praditya, D., Kirchhoff, L., Brüning, J., Rachmawati, H., Steinmann, J., Steinmann, E. 2019. Antiinfective properties of the golden spice curcumin. Front. Microbiol. 10, 1-16. https://doi.org/10.3389/fmicb.2019.00912.

Quintero, A., Fabbro, R., Maillo, M., Barrios, M., Milano, M.B., Fernández, A., Williams, B., Michelangeli, F., Rangel, H.R., Pujol, F.H. 2011. Inhibition of hepatitis B virus and human immunodeficiency virus (HIV-1) replication by Warscewiczia coccinea (Vahl) Kl. (Rubiaceae) ethanol extract. Nat. Prod. Res., 25, 1565-1569. http://dx.doi.org/10.1080/14786419.2010.535164.

Rakibul, I., Mashhood, A.S. 2010. Cultural and socio-economic factors in health, health services and $\begin{array}{lllll}\text { prevention for indigenous people. } & \text { Antrocom. } & 6 & \text { 263-273. }\end{array}$ https://munin.uit.no/bitstream/handle/10037/6912.

Rao, Y.K., Fang, S.H., Tzeng, Y.M. 2005. Anti-inflammatory activities of flavonoids isolated from Caesalpinia pulcherrima. J. Ethnopharmacol. 100, 249-253. https://doi.org/10.1016/j.jep.2005.02.039.

Ravikumar, Y.S., Ray, U., Nandhitha, M., Perween, A., Raja Naika, H., Khanna, N., Das, S. 2011. Inhibition of hepatitis $\mathrm{C}$ virus replication by herbal extract: Phyllanthus amarus as potent natural source. Virus Res. 158, 89-97. https://doi.org/10.1016/j.virusres.2011.03.014.

Rezaire, A., Robinson, J.C., Bereau, D., Verbaere, A., Sommerer, N., Khan, M.K. 2014. Amazonian palm Oenocarpus bataua ("patawa"): Chemical and biological antioxidant activity - Phytochemical composition. Food Chem., 149, 62-70. https://doi.org/10.1016/j.foodchem.2013.10.077.

Rouillé, Y., Helle, F., Delgrange, D., Roingeard, P., Voisset, C., Blanchard, E., Belouzard, S., Mc Keating, J., Patel, A.H., Maertens, G., Wakita, T., Wychowski, C., Dubuisson, J. 2006. Subcellular localization of hepatitis $\mathrm{C}$ virus structural proteins in a cell culture system that efficiently replicates the virus. J. Virol. 80, 2832-2841. https://doi.org/10.1128/JVI.80.6.2832- 2841.

Roumy, V., Garcia-Pizango, G., Gutierrez-Choquevilca, A-L., Ruiz, L., Jullian, V., Winterton, P., Fabre, N., Moulis, C., Valentin, A. Amazonian plants used by Peruvian Quechua and Mestizo people to treat malaria: evaluation of their activity. 2007. J. Ethnopharmacol. 112, 482-489. https://doi.org/10.1016/j.jep.2007.04.009. 
Sahuc, M.E., Sahli, R., Rivière, C., Pène, V., Lavie, M., Vandeputte, A., Brodin, P., Rosenberg, A.L., Dubuisson J., Ksouri, R., Rouillé, Y., Sahpaz, S., Séron, K. 2019. Dehydrojuncusol, a natural phenanthrene compound extracted from Juncus maritimus is a new inhibitor of hepatitis C virus RNA replication. J. Virol. 93. https://doi.org/10.1128/JVI.02009-18.

Salama, S.M., Abdulla, M.A., Alrashdi, A.S., Ismail, S., Alkiyumi, S.S., Golbabapour, S. 2013. Hepatoprotective effect of ethanolic extract of Curcuma longa on thioacetamide induced liver cirrhosis in rats. BMC Complement. Altern. Med., 13, 56-7310.1186/1472-6882-13-56.

Salzano, F.M. 1990. Parasitic load in South American tribal populations. Disease in Populations in Transition: Anthropological and Epidemiological Perspectives. Bergin and Garvey, New York.

Sanz-Biset, J., Cañigueral, S., 2011. Plant use in the medicinal practices known as "strict diets" in Chazuta valley (Peruvian Amazon). J. Ethnopharmacol. 137, 271-288. https://doi.org/10.1016/j.jep.2011.05.021.

San Sebastián, M., Armstrong, B., Cordoba, J. A., Stephens, C. 2001. Exposures and cancer incidence near oil fields in the Amazon basin of Ecuador. Occup. Environ. Med., 58, 517-522.

San Sebastián, M, Armstrong, M., Stephens, C. 2002 Outcome of pregnancy among women living in the proximity of oil fields in the Amazon basin of Ecuador Int. J. Occup. Environ. Health 8, 312-319.

Schmidt, M.E.P., Pires F.B., Bressan L.P., Da Silva, S.V., Lameira O., Da Rosa, M.B. 2018. Some triterpenic compounds in extracts of Cecropia and Bauhinia species for different sampling years. Rev. Bras. Farmacogn. 28, 21-26. http://dx.doi.org/10.1016/j.bjp.2017.11.005.

Séron, K., Sahuc, ME., Rouillé, Y., 2018. Natural products and hepatitis C virus; natural antimicrobial agents. Sustainable development and biodiversity, 19. Springer, Cham.

Shoba, G., Joy, D., Joseph, T., Majeed, M., Rajendran, R., Srinivas, P.S.S.R. 1998. Influence of piperine on the pharmacokinetics of curcumin in animals and human volunteers. Planta Med. 64, 353-356. https://doi.org/10.1055/s-2006-957450.

Staub, P.O., Geck, M.S., Weckerle, C.S., Casu, L., Leonti, M. 2015. Classifying diseases and remedies in ethnomedicine and ethnopharmacology. J. Ethnopharmacol., 174, 514-519. https://doi.org/10.1016/j.jep.2015.08.051

Stohs, S.J. 2014. Safety and efficacy of Bixa orellana (Achiote, Annatto) leaf extracts, Phytother. Res. 28, 956-960. https://doi.org/10.1002/ptr.5088.

Thomas, R., Sah, N., Sharma, P. 2008. Therapeutic biology of Jatropha curcas: A Mini Review. Curr. Pharm. Biotechnol. 9, 315-324. https://doi:10.2174/138920108785161505.

Towne, C.M., Dudt, J.F., Ray, D.B. 2015. Effect of Mansoa alliacea (Bignonaceae) leaf extract on embryonic and tumorigenic mouse cell lines. J. Med. Plants Res. 9, 799-805. https://doi.org/10.5897/JMPR2015.5823.

Webb, J., Mainville, N., 2009. Deforestación, explotación petrolera y salud humana en la cuenca del río Pastaza: informe corto sobre el mercurio y los hidrocarburos aromáticos policíclicos. MeCAA Project. Lima.

WHO (World Health Organization), 2017. Global Hepatitis Report. Geneva. http://apps.who.int/iris. 
Wigg, M.D., Al-Jabri, A.A., Costa, S.S., Race, E., Bodo, B., Oxford, J.S. 1996. In-vitro virucidal and virustatic anti HIV-1 effects of extracts from Persea Americana Mill, (Avocado) leaves. Antivir. Chem. Chemoth. 7, 179-183. https://doi.org/10.1177/095632029600700401.

Wu, S.J., Ng, L.T., Chen, C.H., Lin, D.L., Wang, S.S., Lin, C.C. 2004. Antihepatoma activity of Physalis angulata and P. peruviana extracts and their effects on apoptosis in human Hep G2 cells. Life sci., 74, 2061-2073. https://doi.org/10.1016/j.lfs.2003.09.058.

Yang, G., Chen, D. 2008. Biflavanones, flavonoids, and coumarins from the roots of Stellera chamaejasme and their antiviral effect on hepatitis B virus. Chem. Biodivers. 5. 1419-1424. https://doi.org/10.1002/cbdv.200890130. 


\section{Supplementary data}

Table 1: HCV inhibition at $25 \mu \mathrm{g} / \mathrm{mL}$ and cytotoxicity of the 45 plant extracts

\begin{tabular}{|c|c|c|c|}
\hline $\begin{array}{ll} & \text { Biological activities } \\
(n=3)\end{array}$ & $\begin{array}{l}\text { Infection HCV (\% } \\
\text { at } 25 \mu \mathrm{g} / \mathrm{mL}) \pm \\
\text { SD }\end{array}$ & $\begin{array}{l}\text { Huh-7 nuclei viability (\% } \\
\text { at } 25 \mu \mathrm{g} / \mathrm{mL}) \pm \mathrm{SD}\end{array}$ & $\begin{array}{l}\text { Cytotoxicity on } \\
\text { HepG2 cells } \mathrm{IC}_{50} \\
(\mu \mathrm{g} / \mathrm{mL}) \pm \mathrm{SD}\end{array}$ \\
\hline Bixa Orellana (L) & $6.5 \pm 2.6$ & $88.6 \pm 6.7$ & $196.5 \pm 9.1$ \\
\hline Euterpe precatoria $(\mathrm{R})$ & $6.6 \pm 2.9$ & $90.4 \pm 13.5$ & $163.6 \pm 17.8$ \\
\hline Scleria microcarpa $(\mathrm{R})$ & $7.7 \pm 2.5$ & $85.1 \pm 4.8$ & $>250$ \\
\hline Astrocaryum jauari (R) & $7.7 \pm 1.4$ & $76.5 \pm 4.1$ & $87.4 \pm 10.0$ \\
\hline Phyllanthus stipulatus (R) & $8.7 \pm 2.9$ & $85.2 \pm 19.6$ & $192.6 \pm 10.3$ \\
\hline Oenocarpus bataua (Fr) & $9.6 \pm 6.0$ & $61.2 \pm 13.1$ & $109.2 \pm 23.5$ \\
\hline Scleria microcarpa (AP) & $12.5 \pm 5.8$ & $98.4 \pm 4.4$ & $178.7 \pm 18.2$ \\
\hline Cecropia ficifolia (L) & $21.6 \pm 3.9$ & $96.5 \pm 7.4$ & $221.9 \pm 24.1$ \\
\hline Pouteria caimito (L) & $27.6 \pm 5.8$ & $105.4 \pm 15.9$ & $250.8 \pm 11.4$ \\
\hline Persea americana $(\mathrm{L})$ & $30.6 \pm 6.4$ & $38.2 \pm 17.0$ & $116.5 \pm 19.7$ \\
\hline Physalis angulata (AP+Fr) & $31.2 \pm 9.8$ & $48.6 \pm 6.4$ & $182.2 \pm 7.4$ \\
\hline Maytenus macrocarpa (B) & $41.1 \pm 14.0$ & $113.8 \pm 21.5$ & $108.9 \pm 7.0$ \\
\hline Chamaesyce thymifolia (R) & $41.5 \pm 2.3$ & $104.4 \pm 12.7$ & $193.2 \pm 8.6$ \\
\hline Phyllanthus stipulatus (AP) & $44.9 \pm 1.2$ & $112.7 \pm 25.7$ & $98.4 \pm 4.2$ \\
\hline Chamaesyce thymifolia (AP) & $45.2 \pm 10.7$ & $88.0 \pm 4.0$ & $159.7 \pm 21.4$ \\
\hline Mansoa alliacea (EP) & $45.4 \pm 6.1$ & $96.5 \pm 11.9$ & $218.4 \pm 14.8$ \\
\hline Curcuma longa $(\mathrm{R})$ & $46.4 \pm 19.1$ & $41.0 \pm 13.2$ & $36.2 \pm 6.2$ \\
\hline Caesalpinia pulcherrima (L) & $46.4 \pm 22.9$ & $110.0 \pm 29.5$ & $>250$ \\
\hline Aspidosperma excelsum (B) & $53.6 \pm 18.3$ & $35.1 \pm 21.4$ & $42.6 \pm 21.2$ \\
\hline Gossypium barbadense (FI) & $59.4 \pm 14.8$ & $56.5 \pm 33.9$ & $170.0 \pm 24.2$ \\
\hline Hura crepitans (B) & $59.4 \pm 29.2$ & $79.7 \pm 7.9$ & $>250$ \\
\hline Jatropha curcas (L) & $64.9 \pm 4.9$ & $95.3 \pm 11.9$ & $176.2 \pm 3.3$ \\
\hline Malachra ruderalis (AP) & $66.6 \pm 11.8$ & $103.6 \pm 24.8$ & $>250$ \\
\hline Senna reticulata (FI) & $69.4 \pm 10.1$ & $104.4 \pm 24.8$ & $>250$ \\
\hline Gossypium barbadense (L) & $75.6 \pm 7.4$ & $113.8 \pm 19.7$ & $217.8 \pm 5.8$ \\
\hline Phyllanthus urinaria (EP) & $75.6 \pm 15.2$ & $97.9 \pm 8.3$ & $174.8 \pm 12.4$ \\
\hline Carludovica palmata (L) & $75.8 \pm 6.6$ & $72.5 \pm 8.0$ & $243.4 \pm 24.1$ \\
\hline Cajanus cajan (AP) & $76.7 \pm 10.7$ & $100.1 \pm 26.0$ & $86.2 \pm 31.0$ \\
\hline Oenocarpus bataua (R) & $80.3 \pm 15.4$ & $105.6 \pm 20.9$ & $>250$ \\
\hline Desmodium adscendens (AP) & $81.4 \pm 13.2$ & $99.3 \pm 18.8$ & $>250$ \\
\hline Socratea exorrhiza (L) & $82.1 \pm 6.0$ & $83.7 \pm 17.3$ & $39.3 \pm 18.3$ \\
\hline Astrocaryum jauari (L) & $85.7 \pm 11.7$ & $75.7 \pm 17.5$ & $176.9 \pm 17.7$ \\
\hline Tessaria integrifolia $(\mathrm{R})$ & $86.7 \pm 2.5$ & $78.6 \pm 8.3$ & $170.0 \pm 12.5$ \\
\hline Gynerium sagittatum (AP) & $88.7 \pm 5.4$ & $99.2 \pm 7.8$ & $226.5 \pm 5.6$ \\
\hline Pseudelephantopus spiralis (AP) & $89.5 \pm 21.9$ & $87.4 \pm 18.3$ & $151.9 \pm 8.8$ \\
\hline Carica papaya (S) & $91.0 \pm 7.0$ & $96.4 \pm 10.6$ & $>250$ \\
\hline Eryngium foetidum (EP) & $93.0 \pm 16.8$ & $73.8 \pm 10.7$ & $192.0 \pm 17.0$ \\
\hline Costus erythrocoryne (AP) & $95.9 \pm 13.3$ & $97.2 \pm 14.4$ & $>250$ \\
\hline Tessaria integrifolia (AP) & $96.4 \pm 6.7$ & $94.1 \pm 9.9$ & $108.1 \pm 11.9$ \\
\hline Urera baccifera (AP) & $98.3 \pm 7.7$ & $78.8 \pm 8.2$ & $>250$ \\
\hline Senna reticulata $(\mathrm{L})$ & $99.7 \pm 18.3$ & $100.0 \pm 21.2$ & $213.2 \pm 12.2$ \\
\hline Carica papaya (L) & $102.5 \pm 10.8$ & $101.2 \pm 16.8$ & $>250$ \\
\hline Phytelephas macrocarpa (L) & $103.2 \pm 31.7$ & $100.3 \pm 11.6$ & $188.6 \pm 25.3$ \\
\hline Crescentia cujete (L) & $103.3 \pm 18.9$ & $104.2 \pm 21.3$ & $224.2 \pm 6.3$ \\
\hline Carludovica palmata (HP) & $105.4 \pm 8.1$ & $106.2 \pm 19.7$ & $>250$ \\
\hline
\end{tabular}

